\title{
INTERAÇÃO ENTRE O FUNGO Metarhizium anisopliae. (METSCH.) SOROK., 1883 E OS PRINCIPAIS PARASITÓIDES DA BROCA DA CANA-DE-AÇÚCAR Diatraea saccharalis (FABRICIUS, 1794)
}

\author{
MARIA ELISABETE GERALDI FOLEGATTI \\ Engenheiro Agrônomo
}

Orientador: Dr. SÉRGIO BATISTA ALVES

Dissertação apresentada à Escola Superior de Agrícultura "Luiz de Queiroz", da Universidade de São Paulo, para obtenção do título de Mestre em Ciências Biológicas Área de Concentração: Entomologia.

\footnotetext{
$P$ I R A I C A B A

Estado de São Paulo - Brasil

Setembro - 1985
} 
.ii.

A minha família,

DEDICO. 


\section{AGRADECIMENTOS}

- Ao Dr. Sérgio Batista Alves, Professor Adjunto do Departamen to de Entomologia da Escola Superior de Agricultura "Luiz de Queiroz" (ESALQ), da Universidade de São Paulo (USP), pelo incentivo e orientação segura na condução deste trabalho;

- Aos Docentes do Departamento de Entomologia da ESALQ/USP, pe los ensinamentos transmitidos e atenção dispensada;

- A EMPRESA BRASILEIRA DE PESQUISA AGROPECUÁRIA (EMBRAPA) pela concessão da bolsa de estudos para realização do curso de Mes trado em Entomologia;

- Ao IAA/PlanalsuCAR, nas pessoas do Dr. Paulo Sérgio Botelho e Luiz Carlos de Almeida, pelo fornecimento do material biológico;

- A Financiadora de Estudos e Projetos (FINEP) pelo suporte econômico da pesquisa;

- A biöloga Vera Aun, pelas sugestões valiosas e acima de tudo, pela amizade sincera e estímulos durante o decorrer da pesquisa; 
- A Dră Clarice Garcia Borges Demétrio, pela orientação das análises estatísticas e atenção dispensada;

- A Sra Aurea B. Michelotto pela versão do Summary;

- Ao Paulo José Costa pela realização dos serviços datilogrāfí cos;

Finalmente, mas não por ültimo, aos colegas do curso e as pessoas que direta ou indiretamente contribuiram pa ra a realização desse trabalho. 
RESUMO $\ldots \ldots \ldots \ldots \ldots \ldots \ldots \ldots \ldots \ldots \ldots \ldots \ldots \ldots \ldots \ldots \ldots \ldots \ldots$

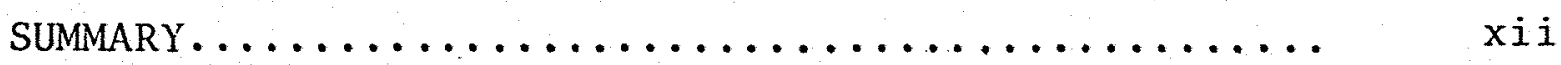

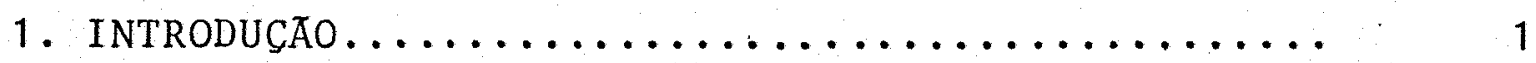

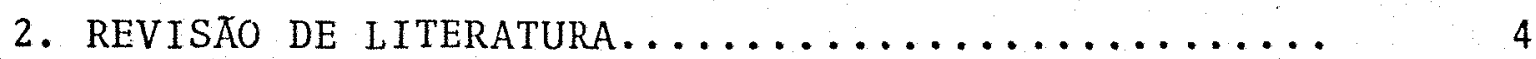

2.1. Metarhizium anisopliae (Metsch.) Sorok...... 4

2.1.1. Classificação............... 4

2.1.2. Utilização do M. anisopliae para o con trole das cigarrinhas...............

2.1.3. Utilização do $M$. anisopliae para o con trole de Diatraea saccharalis (Fabr.)

2.2. Interação entre patógenos e inimigos natu-

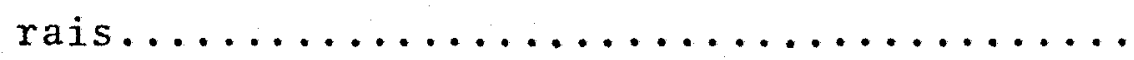

2.2.1. Interação entre fungos e parasitos...

2.2.2. Interação entre outros tipos de pató-

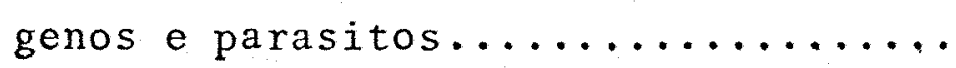

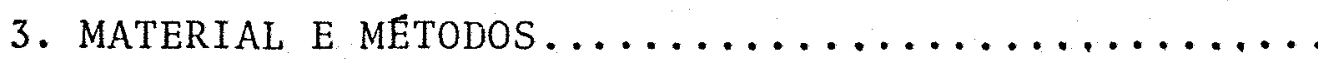

3.1. Material.....................

3.1.1. Isolado do fungo Metarhizium aniso-

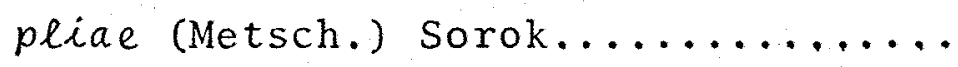

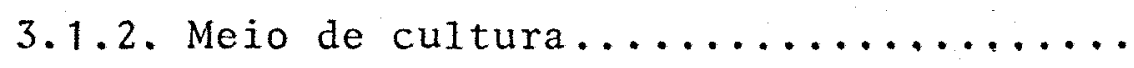


3.1.3. Insetos utilizados nos bioensaios..

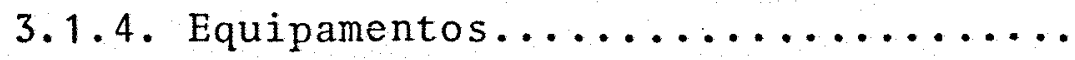

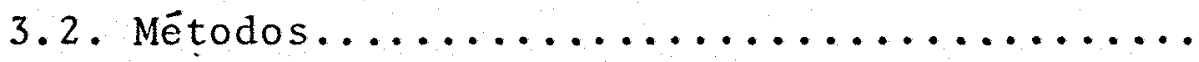

3.2.1. Bioensaios com 1agartas de Diatraea saccharalis (Fabr.) parasitada por Metagonistylum minense (Towns.), Pa ratheresia claripalpis (Wulp.) e Apanteles flavipes (Cam.)..........

3.2.2. Infestação das lagartas com os inse-

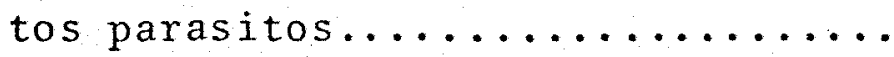

3.2.2.1. Exposição das lagartas de Diatraea saccharalis (Fabr.) à oviposição de Apanteles Glavipes (Cam.)..........

3.2.2.2. Infestação das lagartas de Diatraea saccharalis (Fabr.) com larvas das moscas Meta gonistylum minense (Towns.)

e Paratheresia claripalpis

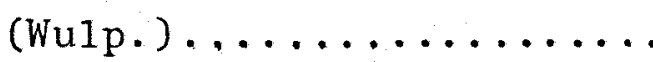

3.2.3. Obtenção do inóculo utilizado nos

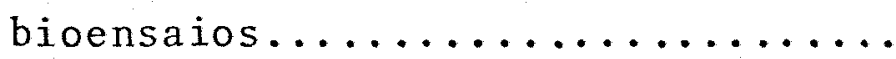

3.2.4. Preparação da suspensão de conídios de Metarhizium anisopliae (Metsch.)

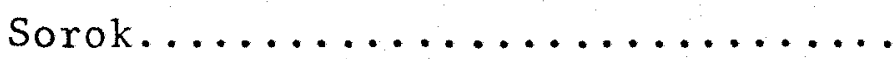


3.2.5. Inoculação das lagartas de Diatraea saccharalis (Fabr.) com o fungo Metarhizium anisopliae (Metsch.) Sorok.

3.2.6. Bioensaios com adultos dos parasitos da broca da cana............

3.2.6.1. Experimento II: Inoculação do Metarhizium anisopliae (Metsch.) Sorok. em adultos de Apanteles flavipes

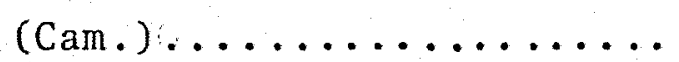

3.2.6.2. Experimento III: Inoculação do Metarhizium anisopliae (Metsch.) Sorok. em adultos de Metagonistylum mi nense (Towns.) e Parathere sia claripalpis (Wulp.)...

3.2.7. Bioensaios com pupas dos parasitos da broca da cana...............

3.2.7.1. Experimento IV: Inoculação do Metarhizium anisopliae (Metsch.) em massas de Apanteles flavipes (Cam.).. 


\subsubsection{Experimento V: Inoculação do} Metarhizium anisopliae(Metsch.) Sorok. em pupas de Metagonis tylum minense (Towns.) e $\mathrm{Pa}$ ratheresia claripalpis (Wulp.)

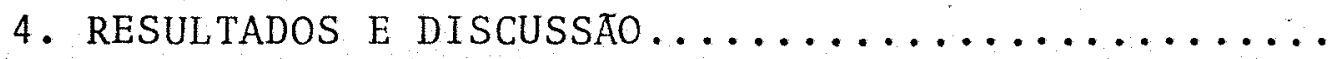

4.1. Experimento I: interação entre os principais parasitos da broca da cana-de-açúcar Diatraea . saccharalis (Fabr.) e o fungo Metarhizium a-

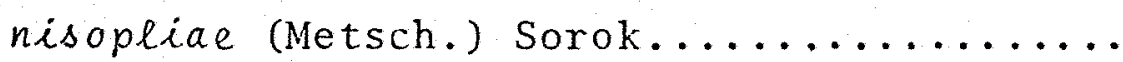

4.2. Experimento II: inoculação do Metarhizium anisopliae (Metsch.) Sorok. em adultos de A-

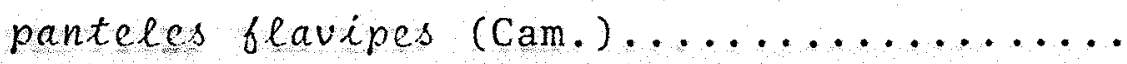

4.3. Experimento III: Inoculasão do Metarhizium a nisopliae (Metsch.) Sorok. em adultos de Metagonistylum minense (Towns.) e parathere-

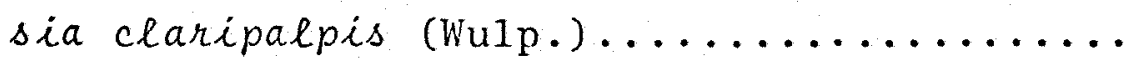

4.4. Experimento IV: inoculação do Metarhizium anisopliae (Metsch.) Sorok. em massas de Apan

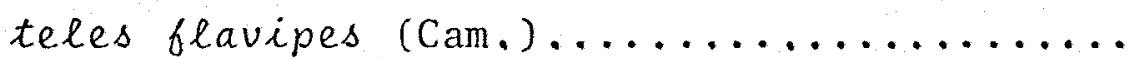

4.5. Experimento V: inoculação do Metarhizium ani sopliae (Metsch.) Sorok. em pupas de Metagonistylum minense (Towns.) e Paratheresia cla

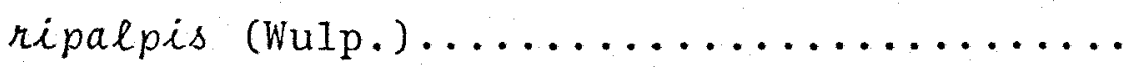


Pägina

5. CONCLUSOES....................... 84

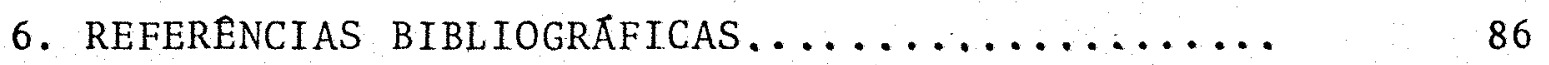




\section{INTERACÃO ENTRE 0 FUNGO Metarhizium anisopliae \\ (METSCH,) SOROK E ES PRIHCIPAIS PARASITÓIDES \\ DA BROCA DA CANA-DE-ACÚCAR Diatraea saccharalis (FABR,)}

Autor: MARIA ELISABETE

GERALDI FOLEGATTI

Orientador: Dr. SERGIO BATISTA ALVES

\section{RESUMO}

A presente pesquisa visou determinar as possiveis interações entre o fungo Metarhizium anisopliae (Metsch.) Sorok. var. minor (Padrão A), isolado PL-43, e os principais $\underline{i}$ nimigos naturais da broca da cana-de-açúcar. representados por Apanteles flavipes (Cam.), Metagonistylum minense (Towns.) e Paratheresia claripalpis (Wulp.), jä que ambos, patögeno e parasitos, vêm sendo utilizados conjuntamente nas regiões canavieiras, do Nordeste do país.

Para se verificar a natureza dessas interaçöes, a praga foi submetida a 8 diferentes condições, combinando-se a inoculação pelo fungo com as inoculações pelos parasitos em três fases de seu desenvolvimento, nas temperaturas de 22,26 e $30^{\circ} \mathrm{C}$. 
Os parâmetros avaliados nesse experimento foram a porcentagem de mortalidade da praga em cada condição, período de desenvolvimento dos parasitos em lagartas de $D$. saccha ralis, período pupal dos parasitos e porcentagem de emergência dos mesmos.

Constatou-se que a aplicação conjunta do $M$. anisopliae associado aos parasitos da broca da cana foi mais eficiente que a aplicação do fungo isoladamente e tambëm que a inoculação do fungo não foi prejudicial aos parasitos quando es te foi inoculado 1,3 e 6 dias após a inoculação das lagartas com os parasitos.

A ação direta do fungo sobre pupas e adultos dos parasitos foi também avaliada nas temperaturas de 22,26 e $30^{\circ} \mathrm{C}$, aplicando-se o patógeno na concentração de $10^{7}$ conídios/ /ml de suspensão. As pupas dos três narasitos foram inoculadas por imersão e os adultos foram inoculados através do contato com recipientes infestados pelo fungo, não tendo sido observado casos de infecção desses estágios pelo M. anisopliae.

Concluiu-se finalmente, que é possível a utilizą ção conjunta do $M$. anisopliae e os parasitos da broca dentro de um esquema de manejo integrado das pragas da cana - de - açücar. 
INTERACTION BETWEEN THE FUNGUS Metarhizium anisopliae (METSCH:) SOROK. AND THE MAIN PARASITOIDS OF THE SUGARCANE BORER Diatraca saccharalis (FABR.)

\author{
Author: MARIA ELISABETE \\ GERALDI FOLEGATTI \\ Adviser: Dr. SERGIO \\ BATISTA ALVES
}

\title{
SUMMARY
}

The present research was aimed at determining the possible interactions between the fungus Metarhizium ani sopliae (Metsch.) Sorok. var. minor (Standard A), isolate PL-43, and the main natural enemies of the sugarcane borer. represented by Apanteles flavipes (Cam.), Metagonistylum minense (Towns.) and Paratheresia claripalpis (Wulp.) since pathogen and parasites have both been simultaneously used in. the sugarcane-growing regions of Northeast Brazil.

In order to assess the nature of these interactions, the pest was subjected to eight different conditions, combining the inoculation by the fungus with the inoculation by the parasites in three different development stages, at the temperatures of 22,26 and $300^{\circ}$. 
The parameters evaluated in this experiment were: mortality percentage for the pest under each condition, period of development of the parasites on larvae of 0 . saccharalis, pupal period of parasites and their emergence percentage. It was found that the simultaneous application of M. anisopliae associated with the parasites of the sugarcane borer was more effective than the sole application of the fungus, and also that the inoculation of the fungus was not harmful to the parasites when these were inoculated 1,3 and 6 days after inoculation of the larvae with parasites. The direct action of the fungus on pupae and adult parasites was also evaluated at the temperatures of 22 , 26 and $30^{\circ} \mathrm{C}$, applying the pathogen in a concentration of $10^{7}$ conidia/ml suspension. The pupae of the three parasites were inoculated by immersion and the adults were inoculated by contact with fungus-infected containers, and no cases were observed of infection by $M$. anisopliae in these stages.

Finally, it was concluded that it is possible to simultaneously use $M$. anisopliae and parasites of the sugarcane borer within a program of integrated management of the sugarcane pests. 


\section{INTRODUCÃ̃O}

Atualmente, a cultura da cana-de-açúcar vem assu mindo posição de destaque no Brasil, devido ao grande incentivo governamental visando a diversificação das fontes energéticas.

A medida que as áreas de cana-de-açücar vêm aumentando è de se esperar um crescimento proporcional da popula ção das pragas chaves da cultura representadas pelas cigarrinhas e brocas, as quais constituem fatores limitantes da produ ção agrícola e industrial resultando em considerāveis prezuízos econômicos.

Atualmente, para o controle da broca da cana Dia traea saccharalis (Fabr.), vêm sendo utilizados os parasitos de lagartas Apanteles flavipes (Cam.), Metagonistylum minense (Towns.) e Paratheresia claripalpis Wulp, os quais são produzi dos em laboratórios e liberados no campo. 
Alëm desses parasitos ocorrem tambëm, em condiçöes naturais, inimigos de ovos da broca da cana como os trico gramatídeos, forficulídeos, carabídeos e outros.

Tambëm, o controle da broca grande da cana castnia licus (Drury) tem sido tentado nas condições do Nordeste brasileiro com a utilização das duas espëcies do fungo Beauveria.

Com relação ao controle da cigarrinha Mahanarua posticata Stal, consjderada uma das pragas chaves da cana, tem sido utilizado o controle microbiano com o fungo Metarhizium a nisopliae (Metsch.) Sorok. Esse tipo de controle vem sendo aplicado em mais de 100.000 ha de cana nas condições do Nordeste brasileiro.

Da mesma maneira, os inimigos naturais de cigarrinhas representados por Salpingogaster nigra (Schin.) e Acmopolynema hervali Gomes, são comumente observados atacando ninfas e ovos.

Como a tendência moderna é dà utilização do mane jo de pragas, o qual visa a associação de diferentes métodos de controle, o emprego dos entomopatógenos deverá ser compatível com os inimigos naturais das diversas pragas da cana.

Apesar da grande utilização do M. anisopliae em programas de controle de pragas da cana-de-açúcar e principalmente, da cigarrinha das folhas no Nordeste, pouco se conhece sobre as possiveis interações desse patógeno com os inimi gos naturais das cigarrinhas e parasitos da broca dentro do a- 
.3 .

groecossistema da cana-de-açúcar.

Sendo assim, a presente pesquisa teve por objeti vo determinar as possiveis interações entre o fungo $M$. aniso pliae var. minor (Padrão A) e os principais inimigos naturais da broca da cana-de-açúcar, representados por A. Glavipes, $M$. minense $e P$. Claripalpis, já que ambos, patógeno e parasitos vêm sendo utilizados conjuntamente na região canavieira do Nordeste. 


\section{REVISÃO DE LITERATURA}

2.1. Metarhizium arisopliae (Metsch.) Sorok.

\subsubsection{C1assificação}

o fungo Metarhizium anisopliae é um patógeno da classe Hyphomycetes, ordem Moniliales, família Moniliaccae. Foi descrito por Metschnikoff em 1879 como Entomophthora anisopliae Metschnikoff, infectando larvas do besouro Anisopliae austriaca. o autor descreveu a espécie desenhando conídios de comprimentos variáveis, porēm no trabalho descreve conídios de 4,8 micrômetros de comprimento. Sorokin, em 1883, estudando a mesma espécie, incluiu-a no gênero Metarhizium citando as dimensōes de 4,8 por 1,6 micrômetros. Assim, o patógeno passou. a ser designado como Metarhizium anisopliae (Metsch.) Sorokin.

Johnson, em 1915, diferenciou as formas major com conídios de 11,9 por 3,0 micrômetros e a minor com conídios de 3,5 por 2,0 a 3,0 micrômetros, as quais ocorrem sobre diferentes 
hospedeiros (PETCH, 1931; STEINHAUS, 1949; KENDRICK, 1971 e TULLOCH, 1976).

TULLOCH (1976) revisou a taxonomia do gênero Metarhizium e manteve duas espëcies: Metarhizium flavoviride (Gams Rozsypa1), Metarhizium anisopliae (Metsch.) Sorok. var. anisopliae (também referida como minor) e Metarhiziun anisopliae (Metsch.) Sorok. var. major (Johnston). o autor considerou sinonímia da espécie M. anisapliae duas outras: (1) M. album, por entender que a forma descrita correspondia a um isolado imaturo de $M$. anisopliae; (2) M. brunneum, porque a julgou um mutante natural cor marrom da forma selvagem de M. anisopliae que é verdeoliva.

2.1.2. Utilizaçáo do fungo $M$. anisopliae para o contro le de cigarrinhas

Quanto ao uso de $M$. anisopliae nas culturas de cana-de-açúcar, RORER (1910) propôs a produção desse fungo, principalmente, devido à facilidade de obtenção de conídjos.

o mesmo autor, em 1913, relatou que, após ter efetuado a aplicação de $2,8 \mathrm{~kg}$ de conídios de $M$. anisopliae por ha, conseguiu uma média de 92 insetos mortos por perfilho de ca na-de-açücar apōs 6 semanas, o que representa aproximadamente 460.000 insetos mortos por hectare. 
No Brasil, GUAGLIUMI (1970) executou o primeiro experimento de controle de cigarrinhas da cana-de-açúcar, utilizando o M. anisopliae, quando obteve resultados muito pro missores. Em 1971 e 1972, continuando seus experimentos, o autor relatou que esse fungo provocou $80 \%$ de mortalidade de ninfas e adultos de cigarrinhas após 15 dias da aplicação. Comuni cou também que a média de mortalidade dos diversos estágios de desenvolvimento do inseto, após 30 a 60 dias da aplicação, em 26 campos tratados, foi de $35^{\circ}$, sendo a mortalidade de ninfas de 40 a $50 \%$.

Da mesma maneira que no Estado de Pernambuco, o fungo contribui para o controle das cigarrinhas nas regiões canaviciras de Campos (RJ) e do sul do Brasil. Tanto no Estado do Rio de Janeiro, como em Santa Catarina esse patógeno ocorre naturalmente (ALVES, inf. pessoa1).

GUAGLIUMI et alie (1974) visando o controle de Mahanarva posticata com o fungo Metarhizium anisopliae, efetuaram aplicações terrestres usando 40 garrafas de Roux do fungo em 400 1itros de água/ha e aplicações aéreas com 30 garra fas/80 1itros de água/ha obtendo 30 a $40 \%$ de mortalidade de ninfas e 20 a $30 \%$ de infecção de adultos. Os autores relataram, que nas āreas tratadas, outros insetos foram colonizados pelo fungo, taj.s como: Diatraea spp., Metamasius hemipterus, Spodoptera frugiperda e Cirphis sp.

AQUINO (1974) constatou em um ensaio experimental com M. anisopliae em cana-de-açucar que ocorreu parasitis 
mo de cigarrinhas pelo fungo 5 dias após a sua aplicação, sendo que o patógeno permaneceu no campo por um período de $18 \mathrm{me}$ ses, causando diferentes graus de infecção nos diferentes estâ gios de desenvolvimento do inseto.

MACEDo et alii (1977) realizaram, na região de Ri beirão Preto, um trabalho de controle de Mahanarva fimbriolata (Sta1.) com M. anisopliae, obtendo na 4 ạ e 8a sema nas 23,36 e $41,49 \%$ de mortalidade, respectivamente.

No Estado de Pernambuco, entre os anos de 1972 e 1978, a ārea tratada com Metaquino passou de 500 para 50.000 ha, obtendo-se um controle de cigarrinhas altamente satisfatório. O IAA/PLANALSUCAR adotou um programa similar, na unidade de pro dução de Maceió (AL), capaz de fornecer material suficiente pa ra tratar diariamente 100 ha de cana-de-açúcar.

Segundo RISCO (1978), para o controle biolögico de Mahanarua posticata utilizou-se o fungo Metarhizium ani sopliae em diferentes formulações em 20.000 ha de cana-de-aşucar nos anos $1977 / 78$, obtendo-se uma redução na infestação por ninfas e adultos. Já no ano de 1979, a área tratada com o fungo foi 53.554 ha, só no Estado de Alagoas, sendo 38.994 ha aplica dos por via terrestre e 16.610 ha por via aêrea, com aproximadamente $33 \%$ de infecção de ninfas (MENDONCA e COSTA, 1980).

Em 1980, a ärea total de cana..de-açücar tratada com o fungo Metarhizium anisopliae foi de 101.105 ha abrangendo os estados de Alagoas, Pernambuco, Paraíba e Rio Grande do Norte, obtendo-se uma mortalidade média de $23,14 \%$ para nin- 
fas e $40,39 \%$ para adultos de Mahanarva posticata. Dessa forma, - fungo entomógeno Metarhizium anisopliae é atualmente o mais importante agente de controle da cigarrinha M. posticata (MARQUES, 1981).

Atualmente, a ESALQ/IAA/PLANALSUCAR estão executando um projeto que visa estudos básicos e aplicados com o fun go $M$. anisopliae para o controle da cigarrinha $M$. posticata.

Com relação ao controle de cigarrinhas das pasta gens o $M$. anisopliae ven sendo muito utilizado nos Estados da Bahia, Espirito Santo, Mato Grosso, Mato Grosso do Sul, Goiās, Paraná, Minas Gerais e São Paulo, obtendo-se resultados bastan te contraditórios. Segundo ALVES (1982), isso se deve a alguns aspectos importantes tais como: qualidade do fungo, quantidade do fungo aplicada por unidade de área, seleção de raças e a fal ta de pesquisas básicas.

Dessa forma, PACHECO e BERNARDES (1976), testando três concentraçōes de $M$. anisopliae contra zulia entreriana, no Espírito Santo, não obtiveram resultados positivos devido à fal ta de umidade na época da aplicação do fungo e à baixa densida de populacional do hospedeiro. No entanto, VEIGA (1979), em tes tes de laboratörio com Aeneolamia selecta e Deois incompleta, ob teve cerca de $100 \%$ de controle para ninfas e adultos. Por outro lado, para condições de campo, o autor constatou a existên cia de um condicionamento ecológico acentuado em relação à $\underline{\text { e }}$ ficiência de controle das cigarrinhas pelo fungo $M$. ancisopliae em suspensão aquosa de esporos, já que, das cinco localidades 
pulverizadas, em apenas três obteve controle satisfatório. VILLACORTA (1980) testou diferentes isolados de M. anisopliae sobre ninfas de Deois flavopicta e observou a existência de uma grande variação no grau de eficiência dos diferentes isolados de M. anisopliae, o que indica a existência de especificidade destes isolados, e que os diferentes graus de especificidade estão ligados a determinadas condições de temperatura e umidade relativa.

FERRAZ et alii (1980), com o objetivo de avaliar a eficiencia do $M$. anisopliae no controle das cigarrinhas das pastagens, testaram as dosagens de $600,900,1.200 \mathrm{e} 1.500 \mathrm{~g} / \mathrm{ha}$. Segundo os autores, embora o ensaio não tenha mostrado diferen ças estatisticas entre as dosagens do fungo, foi observada diferença entre a testemunha e os demais tratamentos com relação aos adultos. Por outro lado, nâo houve diferenças entro os tra tamentos para ninfas.

COSENZA et alii (1981) fazem referência ao $M \cdot a-$ nisopliae para controle integrado das cigarrinhas das pastagens, ressaltando a necessidade de condições ecológicas favora veis e do uso de uma cepa selecionada do fungo que possua caracteristicas adequadas.

Dessa forma, NAVES (1981), testando duas linhagenside Metarhizium anisopliae sobre Deois flavopicta e Zulia entreria na, obteve níveis de infecção variando de 60 a $90 \%$, tendo concluía que a cepa E-9 foi mais virulenta que a cepa E-6. NAVES e TEIXEIRA ALVES (1983) publicaram um procedimento teörico para compara 
ção de linhagens e dosagens de $M$. anisopliae em campo.

\subsubsection{Utilização do M. anisopliae para o controle de Diatraea saccharalis (Fabr.)}

Com relação à utilização do Metarhizium anisopliae (Metsch.) Sorok. para controle da broca da cana-de-açücar Diatraea saccharalis (Fabr.), sabe-se que o fungo è patogênico para todos os estägios de desenvolvimento da praga.

GUAGLIUMI et alii (1974) fez a primeira referência sobre o M. anisopliae colonizando Diatraea spp. em äreas de cana-de-açúcar submetidas ao tratamento com o fungo para o controle de cigarrinhas. Posteriormente, ALMEIDA et alii (1981a), estudando o efeito de diversas dosagens do $M$. anisopliae isola do SPL-3B em lagartas de $D$. saccharalis, concluíram que $50 \%$ da população de lagartas e crisāilidas poderiam morrer com dosagens de $4,7 \times 10^{5}$ a $2,9 \times 10^{6}$ esporos/gota (aproximadamente $10 \mathrm{mi}$ crolitros), no 69 dia e de $2 \times 10^{5}$ e $1,6 \times 10^{6}$ esporos/gota no 9 ? dia.

ALMEIDA et alii (1981b e 1981c) estudaram tambëm em condições de laboratório os efeitos do M. anisoplial so bre ovos de $D$. saccharalis obtendo resultados excelentes de con trole.

ALMEIDA e ALVES (1982). efetuaram biotestes, vi- 
sando provar a patogenicidade do M. anisopliae para $D$. saccharalis, obtendo um controle da ordem de $100 \%$ para lagartas de broca da cana, quando inoculadas por "rolamento", com potencial de inóculo de $10^{6}$ conídios por larva, caracterizando o M. anésopliae como um possível agente controlador e sugerindo o seu uso em programas de controle biológico.

Ainda sobre Diatraea saccharalis, ALMEIDA (1983)

concluiu que o fungo entomopatógeno $M$. anisopliae apresenta "in vitro" alta eficiência no controle de ovos e larvas da broca da cana-de-açúcar e que tanto as lagartas provenientes de ovos inoculados com $M$. anisopliae quanto as pupas provenientes de larvas inoculadas, também são colonizadas pelo fungo. 0 autor concluiu ainda que os ovos de $D$. saccharalis com 1 a 3 dias de idade, inoculados com uma suspensão de aproximadamente $1,0 \times 10^{7}$ conidios/mI de $M$. anisopliae anresentam taxa de mortalidade su perior a $79 \%$.

\subsection{INTERAÇÃO ENTRE PATÓGENOS E INIMIGOS NATURAIS}

\subsubsection{Interação entre fungos è parasitos}

E muito provável que alguns entomopatógenos pos sam influenciar populações de parasitos e espécies predadoras, porêm no geral, muito menos do que os inseticidas químicos. As sim, ROCKWOOD (1950) relatou que o fungo Metarhizium anisopliae 
(Metsch.) Sorok. foi encontrado em 1928 em larvas de Porosogro tis vetusta (Walver) e tambëm em seu parasito do gênero Amplyteles.

BELL e HAMALE (1971) demonstraram que quando po pulações de campo de larvas de chalcodermus aeneus, jāestressadas pela bactéria Serratia marcescens e o parasito Myophasia globosa são tratados com Metarhizium, altas concentrações de esporos são menos efetivas do que as concentrações mais baixas. Salientaram também, que com esses patógenos, o nível de a tividade antagônica obtido pelo teste estava entre 0,4 e $1,6 x$ $10^{6}$ esporos de Metarhizium por grama de solo.

BURLEIGH (1975). relatou que o parasitismo por Microplites croceipes no campo pode ser reduzido pela interferência do fungo Nomuraea rileyi.

Nos EUA, estudos de campo mostraram uma relação inversa entre a incidência de doenças fúngicas e o parasitismo por espécies de himenópteros em populações de Thyridopteryx ephemeraeformis. Esse fato foi atribuido a diferentes respostas do fungo e do parasito a condições do tempo (BERISFORD e TSAO, $1975)$.

Por outro lado, SMITH et alii (1976) relataram que Microplitis croceipes e Nomuraea rileyi foram os maiores nimigos naturais de espécies de Heliothis no Mississipi, sendo que ambos foram predominantes durante a úitima estação e M. cro ceipes, ocasionalmente completou seu desenvolvimento na lagarta hospedeira, a qual tambëm mostrou sintomas de infecção por 
N. rileyi.

Baseados nesses dados, KING e BELL (1978) inves tigaram alguns aspectos da interação entre Microplitis croceipes e Nomuraea rileyi verificando que quando a lagarta hospedeira Heliothis zea era parasitada pelo M. croceipes e imediatamente apös, tratada com o fungo, a taxa de parasitismo normal de $M$. croceipes reduzià e o nümero infectado com 0 fungo aumentava. Por esse fato, pode-se concluir que o parasitóide pre dispôs o hospedeiro à infecção pelo fungo. Contudo, a redução do parasitismo foi atribuida, especialmente quando este foi "inoculado" após 3 e 7 dias da inoculação com o fungo, à diminui ção de suscetibilidade das lagartas, devido a sua idade avança da. A diminuição após 1 dia foi relacionada com um possível an tagonismo entre patógeno e o desenvolvimento da larva do para sitöide.

Tambëm, EL-SUFTY e FÜHER (1981) estudaram a inter-relação entre Apanteles glomeratus e o fungo Beauveria bas siana sobre Pieris brassicae concluindo que $P$. brassicae se tor nou mais sensivel ao fungo devido aos efeitos patofisiológicos das larvas de Apanteles sobre sua cutícula. Contudo, após a penetração, o fungo desenvolveu-se mais vagarosamente em larvas parasitadas do que em larvas não parasitadas, o que significa que as larvas parasitadas teriam uma grande chance de escapar da infecção letal pelo fungo.

McCOY (1981) relatou que apesar dos hospedeiros de Hirsutella thompsonie serem principalmente limitados à ordem Acarina, somente Typhlodromalus peregrinus, entre os äcaros 
predadores, tem sido encontrado infectado por esse fungo. Outros predadores invertebrados e parasitos nunca foram encontra dos afetados adversamente em aplicações artificiais de H. thomp sonii. Porém, ALVES (comunicação pessoa1) encontrou um fungo do gênero Hirsutella parasitando insetos da ordem Dermaptera.

Segundo IGNOFFO et alii (1976) e PHADKE e RAO (1978), três predadores Hippodamia convergens, Chrysopa carnea, Podisus maculiventris e três parasitos voria ruralis, Apanteles marginiventris e Campoletis sonorensis e um parasito de ovos Telenomus proditor, não são suscetiveis ao fungo Nomuraea rileyi quando expostos a doses de conídios cerca de 25 vezes maiores do que aquelas usadas em experimentos de campo para in duzir epizootias.

$2 \cdot 2.2$. Interação entre outros tipos de patógenos e parasitos

KAYA (1978) relatou a interação do nematóide Neoaplectana carpocapsae com Apanteles militaris, un parasitöide das lagartas de Gereais Pseudaletia unipuncta, ressaltando que a raça $\mathrm{DD}-136$ do nematóide pode afetar indiretamente o parasitóide, matando o hospedeiro antes que A. militaris pos sa completar seu desenvolvimento. Assim, lagartas contendo para sitóides em estágios avançados de desenvolvimento produzem alta porcentagem de casulos normais quando comparadas com aque- 
las contendo parasitóides em estágios iniciais de desenvolvimento. o autor concluiu também, que o nematöide é capaz de infectar adultos e pupas cujo casulo não esteja formado por ocasião do con tato com o patögeno. No entanto, A. militaris parece não ter efeito adverso sobre $N$. carpocapsae, que pode se desenvolver e re produzir em larvas do hospedeiro de onde o parasitóide tenha emergido.

VAIL et alii (1972), estudando o efeito dos defen sivos químicos e microbianos sobre dípteros e himenópteros para sitos de lepidopteros pragas da cultura da alface, concluíram que os inseticidas químicos têm um efeito severo sobre esses parasitos (28\% das larvas parasitadas na testemunha contra $1,1 \%$ nos canteiros tratados com químicos) enquanto que os inseticidas microbianos têm um efeito deletério sobre os mesmos (28\% con tra 5,2 a $15,4 \%$ o que pode limitar o controle pela combinação de patógenos e parasitos.

BRACKEN e BUCHER (1967), em uma nota sobre a mortalidade de himenópteros parasitos causada por Serratia marcescens, relataram que a sobrevivência das larvas do parasito foi em torno de $90 \%$ (normal) durante 5 gerações. Contudo, apesar das larvas que ingerem as bactérias do hospedeiro não sofrerem os $\underline{e}$ feitos deletérios, quando transformam em adultos, são capazes de transmitir o patógeno para outros adultos que sofrem septice mia total.

Da mesma forma, BELL et alii (1974), estudando a inter-relação de Heliothis zea com Microplites croceipes e a bac 
téria Serratia marcescens, observaram que a alimentação de parasitos adultos com $S$. marcescens resultou em $79^{\circ}$ de mortalidade em 7 dias. No entanto, quando o parasito se desenvolve dentro de hospedeiros infectados, essa patogenicidade não é tão evidente. Contudo, a porcentagem de emergência de $\underline{\text { a }}$ dultos do parasito, sugeriu uma interação antagônica entre a bactéria e o desenvolvimento do parasito. Com relação ao hospedeiro, os autores con cluíram que quando o efeito dos 2 estressores foi combinado, alta mortalidade foi observada.

Tambẻm efetiva redução do parasitismo por solenotus intermedium e Halticoptera aenea em Liriomyza spp. (SHOREY e HALL, 1963) e por Apanteles glomeratus e Phanerotoma blavitestacea em Pieris brassicae e Ephestia kueniella (MARCHALSEGAULT, 1974) tem sido atribuido ao Bacillus thuringiensis. Ingestão de esporos de $B$. thuringiensis reduziu a longevidade de Cardiochiles nigriceps, porēm a exposição deste parasito ou do predador, Jalysus spinosus, ao $B$. thuringiensis não infiuiu na longevidade destes (DUNBAR e JOHNSON, 1975).

Por outro 1ado, JAQUES (1965) relatou que, em um pomar de maçãs no Canadá em que o $B$. thuringiensis foi o único inseticida aplicado por um período de 4 anos, somente um hemíp tero predador Antractonomus mali foi extingüido.

No entanto, a compatibilidade de $B$. thuringien sis e espécies predadoras foi adicionalmente indicada por consistente redução das populações de larvas de Lymanthria dispar em florestas do nordeste dos U.S.A., tratadas com B. thuringien sis em conjunto com 1iberação do parasito Apanteles melonosce- 
lus (WOLLAM e YENDOL, 1976 e AHMAD et alii, 1978).

Segundo Forsberg (1976), citado por JAQUES e MORRIS (1981) numa avaliação crítica do impacto de B. thuringiensis no ambiente, não houve evidências, de que essa bactëria foi antagônica para parasitos ou predadores.

No tocante aos relatos sobre a diminuição do parasitismo em parcelas tratadas com o $B$. thuringiensis, as cau sas não foram determinadas, nem testada a infectividade da bac téria para as espécies não visadas, mas é possível que a redução da taxa de parasitismo tenha resultado da diminuição da po pulação do hospedeiro.

Com relação ao uso combinado de parasitóides e viroses, LAIGO e PASCHKE (1968) encontraram que o período para a emergência do adulto do parasito Pteromalus sp., foi encurta do por tratamento de larvas do hospedeiro Pieris rapae com G.V. Os resultados mostraram que os microrganismos interferem no de senvolvimento dos entomófagos parasitos, quando ambos, microrganismo e parasito estão presentes ao mesmo tempo no hospedeiro.

O parasitöide Apanteles militaris é suscetível, em seus estágios embrionärio e larval, a uma toxina produzida durante a infecção de G.V. em lagartas de Pseudaletia unipuncta. Ovos do parasitóide, quando colocados em lagartas contamina das pelo vírus, não completam seu desenvolvimento embrionärio (KAYA, 1970). 
Também KAYA e TANADA (1973) observaram que o desenvolvimento do parasitóide Apanteles militaris foi prejudi cado quando o plasma não fracionado de lagartas de Pseudaletia unipuncta infectadas por uma raça hipertrófica do seu NPV foi injetado dentro do hospedeiro.

Em outro estudo de laboratório, infecções de He liothis virescens com NPV dentro de dois dias após a oviposí ção por Campoletis sonorensis reduziram substancialmente a sobrevivência do parasito (IBARAGON e BROOKS, 1974). Similarmente, o parasito Hyposoter exiguae morreu em lagartas de Thichoplusia ni expostas a NPV, dois ou mais dias antes e quatro dias após o parasitismo (BEEGLE e OATMAN, 1975).

De acordo com REARDON e PODGWAITE (1976), a inci dência de NPV foi positivamente correlacionada com a incidência de parasitóides en populaçóes de Lumanthria dispar no leste dos USA indicando ser mutuamente vantajosa a ação conjunta.

Por outro lado, DILAWARI et alii (1981), em observações de campo, relataram que durante o pico populacional de Mythimma separata, o parasitismo larval por Apanteles rufricus foi em torno de $95^{\circ}$ e que viroses contribuíram para o declínio da praga antes dela atingir o estágio pupal.

TANADA (1955) relatou a interação no campo entre Apanteles glomeratus e o protozoärio Perezia mesmeli, sobre Pieris rapae. As larvas do braconídeo encontradas em lagar tas infectadas de pieris rapae foram também infectadas, assim como os adultos que desenvolveram-se destas. No entanto, o au- 
tor observou que, os ovos depositados por fêmeas infectadas do parasito, eram viáveis.

THOMSON (1958) relatou que o microsporídeo Pere zia fumiferanae exerce uma influência adversa sobre as larvas dos parasjtos Apanteles fumiferanae e Glypta fumiferanae em 1a gartas de choristoneura fumiferana.

Da mesma forma, IAIGO e TAMASHIRO (1967) e LAIGO e PASCHKE (1968) concluíram que as larvas de Apanteles criadas em lagartas infectadas por Nosema apesar de não demonstrarem nenhuma mudança histopatológica, foram menores, viveram me nos, e foram fisiologicamente afetadas, tanto que, a eficiência total foi reduzida. No entanto, os autores ressaltaram, que esses efeitos deletérios de redução da população de adultos do parasito, provavelmente são mais do que compensados pela habilidade do parasito em transmitir o patógeno.

Também, HOSTOUNSKY (1970) demonstrou histologi camente a infecção de Apanteles gloreratus, Hyposoter ebenimus e Pimpla instigator, todos parasitóides de Pieris brassicae, pelo patógeno Nosema mesnili com materiais coletados no campo, e concluiu que a infecção ocorre através de diferentes vias, tais como, alimentação co pa rasitóide em tecidos infectados do hospedeiro; transmissão através de ovos do parasitóide ou através do contato das larvas ou adultos do parasitóide com tecidos infectados do hospedeiro.

BROOKS e CRANFORD (1972) mostraram que Nosema heliothidis pode infectar o braconídeo parasito campoletis sonorensis quando este se desenvolve em lagartas infectadas de 
Heliothis zea. Todos os estágios de $C$. sonorensis mostraram in fecção sistêmica, e o patógeno foi transmitido transovarianamente por fêmeas infectadas do parasito. Apesar de não ter havido efeito substancial sobre o período de desenvolvimento de C. so norensis em lagartas infectadas, após a emergência como pré-pu pas, $23,1 \%$ destas, não atingiram o estágio adulto.

BROOKS (1973) fez uma revisão detalhada sobre os tipos de inter-relação entre hospedeiros-parasitos e protozoários patogênicos sendo a discussão centrada no papel dos in setos parasitos na transmissão mecânica de protozoários, no de senvolvimento do parasito em hospedeiros infectados por protozoários, na transmissão transovariana do protozoārio do hospedeiro pelo parasito, alēm de outros aspectos.

Os protozoários Glugea gasti e Nosema pyrausta afetaram adversamente o desenvolvimento de Bracon mellitor (BELL e McGOVEN, 1975) e Macrocentrus grandii (ANDREASIS, 1980) que parasitam Anthonomus grandis e ostrinia nubilalis, respectivamente.

Mais recentemente, HAMM et alii (1983) concluiram que Vairimorpha sp. poderia ser usada em conjunto com Cotesia (=Apanteles) marginiventris ou Microplitis croceipes no controle biológico de Heliothis zea devido ao fato de que o pa tógeno não pareceu reduzir a efetividade desses parasitóides. 


\section{MATERIAL E MÉTODOS}

\subsection{MATERIAL}

3.1.1. Isolado do fungo Metarhizium anisopliae Metsch.) Sorok.

0 presente estudo foi desenvolvido no laboratório de Patologia de Insetos do Departamento de Entomologia da ESALQ/USP, Piracicaba, SP.

o patógeno utilizado foi o Metarhizium anisopliae (Metsch.) Sorok. isolado PL-43, originalmente obtido de cigarrinhas Mahanarva posticata (Stal.) proverientes da Usina Peixe, Fleixeiras, Estado de Alagoas. Esse isolado apresentou o padrão A, conforme a Figura 1, segundo ALVES et alii (1983). 


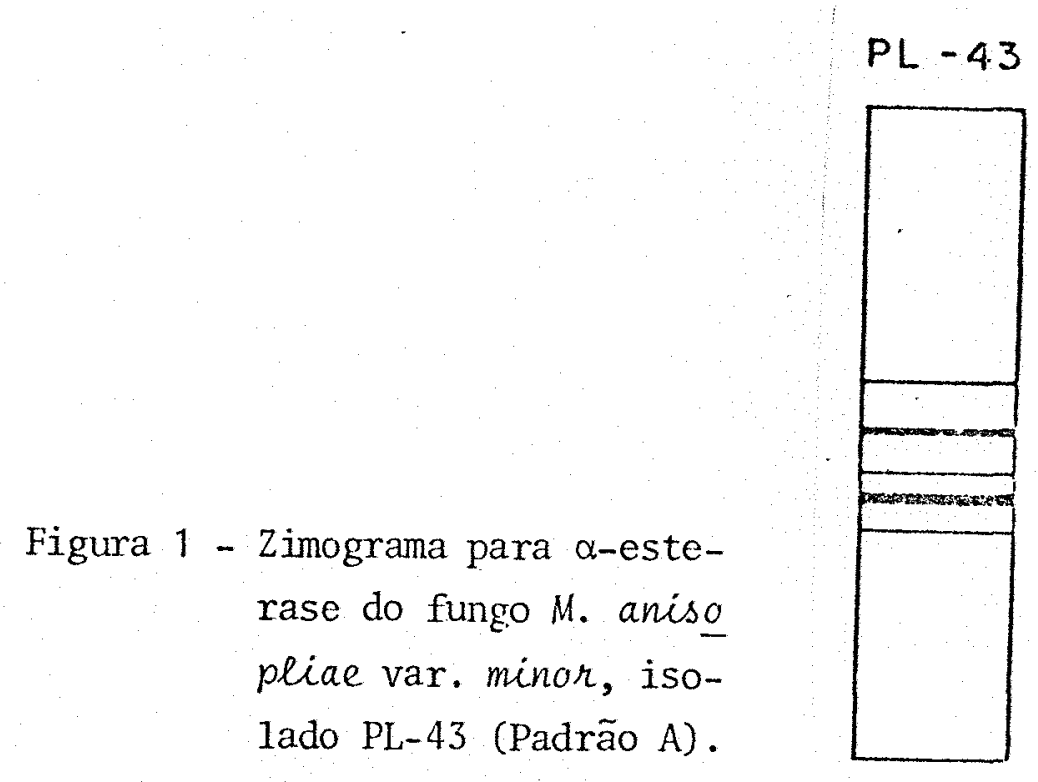

3.1.2. Meio de cultura

Meio: Ágar-batata-dextrose + antibiótico (ABD + antibiótico)cuja fórmula é a seguinte:

- batata sem casca............... $200 \mathrm{~g}$

. dextrose...................... $15 \mathrm{~g}$

- ágar...................... $20 \mathrm{~g}$

- Streptoduocin veterinärio.......... 0,5 g

- água destilada, completar atē........ $1000 \mathrm{ml}$ 
3.1.3. Insetos utilizados nos bioensaios

\author{
Broca da cana-de-açucar: Diatraea saccharalis \\ (Fabr., 1794)
}

Provenientes da criação do laboratório de Controle Biológico do IAA/PLANALSUCAR, criadas em dieta artificial de HENSLEY e HAMMOND, modificada pelo IAA/PLANALSUCAR MEN DES et alie, 1980). As lagartas utilizadas no ensaio, foram na maioria do 4 ? instar.

\title{
Mosca do Amazonas: Metagonistylum minense (Towns., 1926)
}

Oriundos da criação do laboratório de Controle Biológico do IAA/PLANALSUCAR, criados sobre lagartas de Diatraea saccharalis.

Mosca Paratheresia: Paratheresia claripalpis (Wulp., 1896)

Provenientes da criação do laboratório de Controle Biológico do IAA/PLANALSUCAR, criados sobre Diatraea saccharalis. 


\section{Micro-himenóptero: Apanteles blavipes}

(Cam., 1891)

Oriundos da criação do laboratório de Controle Biológico do IAA/PLANALSUCAR, criados sobre Diatraea saccharalis.

\subsubsection{Equipamentos}

- capela de fluxo vertical marca VECO, modelo VLFS-09, que proporcionou as condições de assepsia para os trabalhos de isolamento, purificação e inoculação.

- estufa incubadora BOD, marca FANEM, mode1o 347-G, equipada com lâmpada fluorescente modelo F 15-T 12/LD.

- balança marca METTLER, com indicadores digitais, modelo PB300 e balança analítica marca BOSCH, modelo S-2000.

- agitador elétrico, marca ETICA, para homogeinização da.. suspensão do inöculo (com capacidade de 108 rotações/min até 310 rotações/min).

- microscópio comum OLYMPUS.

- câmara de Neubauer destinada a quantificação do inóculo. 
- câmara de inoculação de plästico, de $6 \mathrm{~cm}$ de diâmetro por $2 \mathrm{~cm}$ de altura (Figura 2).

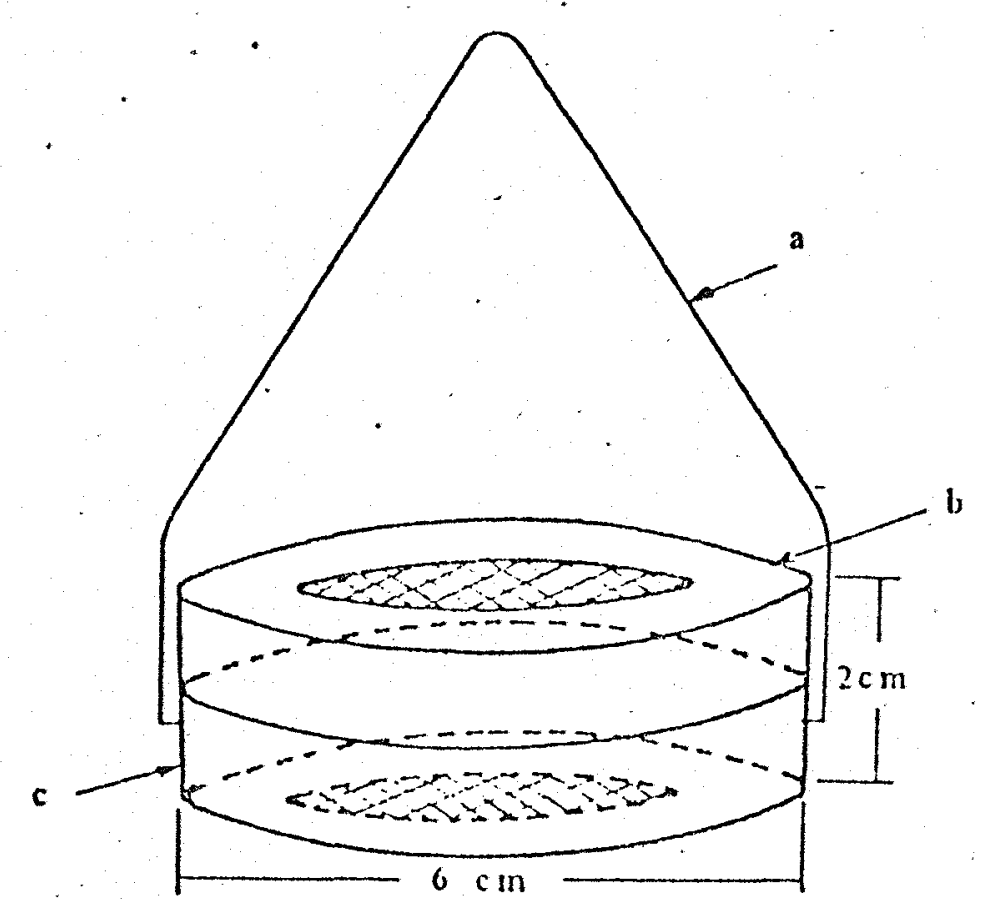

Figura 2 - Câmara de inoculação de plástico:
a) suporte de arame;
b) tampa desmontävel;
c) base.

- gaiolas teladas para a inoculação dos adultos dos parasitos.

- outros materiais: estufa nara esterilizar a seco, autoclave, placas de Petri, alça de Drigalsky, alça de platina, algodão, ā1cool, solução de hipoclorito de sōdio $5 \%$, água destilada esterilizada com espalhante adesivo Agra1 1\%, pinças, pa pel de alumínio, papel filtro, lâminas, erlenmeyer, becker, pipeta automática de duplo estágio modelo pipemat de 5 e 10 microlitros e bisturis. 


\subsection{MÉrodos}

3.2.1. Bioensaios com lagartas de Diatraea saccharalis (Fabr.) parasitada por Metagonistylum minense (Towns.), Paratheresia claripalpis (Wulp.) e Apanteles flavipes (Cam.)

Para se verificar a possivel interação entre os parasitos e o fungo $M$. anisopliae efetuou-se o seguinte bioensaio que foi denominado de Experimento I.

0 delineamento experimental foi em blocos casua lizados, esquema fatorial com 8 condições da praga e 3 fases de aplicação do fungo totalizando 24 trátamentos.

Foram utilizadas 20 lagartas por parcela, perfa zendo um total de 480 lagartas no experimento.

Esse experimento foi realizado seis vezes na tem peratura de $26^{\circ} \mathrm{C}$ e três vezes nas temperaturas de 22 e $30^{\circ} \mathrm{C}$, sen do cada montagem considerada um bloco.

Os tratamentos foram os seguintes:

- FASE 1: lagartas de 49 instar de Diatraea saccharalis (Fabr.) parasitadas por Metagonistylum minense (Towns.), Paratheresia claripalpis (Wulp.) e Apanteles flavipes (Cam.) e após 1 dia inoculadas com o fungo Metarhizium anisopliae. 
- Condição I: lagartas do 49 instar de 0 . saccharalis criadas normalmente em dieta natural (pedaços de colmo de cana-de-açūcar).

- Condição II: lagartas de 49 instar de $D$. saccharalis inocu ladas com a suspensão de conídios de M. anisopliae.

- Condição III: lagartas de 40. Instar de $D$. saccharalis submetidas à oviposição de $A$. Glavipes.

- Condição IV: lagartas de 4 o instar de 0 . saccharalis subme tidas à oviposição de A. flavipes e após um dia, inoculadas com M. anisopliae.

- Condicão V: lagartas de 49 instar de 0 . saccharalis submetidas à larviposição de M. minense.

- Condição VI: lagartas de 49 instar de $D$. saccharalis subme tidas à larviposição de M. minense e após um dia, inoculadas com M. anisopliae.

- Condição VII: lagartas de 49 . Instar de D. saccharalis sub-: metidas à Iarviposição de P. claripalpis.

- Condição VIII: lagartas de 49 instar de 0 . saccharalis sub 
metidas à larviposição de P. claripalpis e após um dia, ino culadas com M. anisopliae.

- FASE 2: lagartas de 49 instar de D. saccharalis parasitadas por M. minense, P. claripalpis e A. flavipes e após 3 dias, inoculadas com o fungo M. anisopliae.

- Condição I: lagartas de 40. Instar de D. saccharalis criadas em dieta natural.

- Condição II: lagartas de 49 instar de 0 . saccharalis inocu ladas com suspensão de conĩdios de M. anisopliae.

- Condição III: lagartas de 49 Ínstar de 0 . saccharalis submetidas à oviposição de Apanteles flavipes.

- Condicão IV: lagartas de 4 ọ. Ínstar de 0 . saccharalis subme tidas à oviposição de A. flavipes e após 3 dias, inoculadas com M. anisopliae.

- Condição V: lagartas de 49 instar de D. saccharalis, subme tidas à larviposição por $M$. minense.

- Condição VI: lagartas de 49 instar de 0 . saccharalis subme tidas à larviposição por M. minense e apōs 3 dias, inoculadas com M. anisopliae. 
- Condição VII: lagartas de 49 instar de $D$. saccharalis submetidas à Iarviposição por $P$. claripalpis.

- Condição VIII: lagartas de 49 instar de $D$. saccharalis sub metidas à larviposição por $P$. claripalpis e após 3 dias inoculadas com $M$. anisopliae.

- FASE 3: lagartas de 49 instar de $D$. saccharalis parasitadas por M. minense, P. claripalpis e A. flavipes e após 6 dias, inoculadas com o fungo M. anisopliae.

- Condição I: lagartas de 4 ! Instar de D. saccharalis criadas normalmente em dieta natural:

- Condicão II: lagartas de 49 instar de 0 . saccharalis inocu ladas com suspensão de conídios de M. anisopliae.

- Condição III: lagartas de 49 ínstar de 0 . saccharalis submetidas à oviposição por A. Glavipes.

- Condição IV: lagartas de 49 instar de D. saccharalis subme tidas à oviposição por A. blavipes e após 6 dias, inocula das com M. anisopliae.

- Condição V: lagartas de 49 instar de D. saccharalis submetidas à larviposição por M. minense. 
- Condição VI: lagartas de 49 ínstar de $D$. saccharalis subme tidas à larviposição por $M$. minense e após 6 dias, inocula das com M. anisopliae.

- Condição VII: 1agartas de 40̣ Instar de D. saccharalis submetidas à larviposição por $P$. claripalpis.

- Condição VIII: lagartas de 49 . Instar de D. saccharalis sub metidas à larviposição por $P$. claripalpis e após 6 dias, i noculadas com M. anisopliae.

3.2.2. Infestação das lagartas com os insetos parasitos

Essa fase do trabalho foi realizada no laborató rio de Controle Biológico do IAA/PLANALSUCAR de Araras, SP. De pois de submetidas ao parasitismo, as lagartas eram transporta das para o laboratório de Patologia de Insetos da ESALQ - USP, em Piracicaba, SP.

As metodologias para o desenvolvimento dessa fa se, foram as normalmente utilizadas nos laboratórios de Contro le Biológico da ESALQ e IAA/PLANALSUCAR, conforme serão descrí tas. 
3.2.2.1. Exposição das lagartas de Diatraea sạ charalis (Fabr.) à oviposição de Apanteles flavipes (Cam.)

Em uma gaiola de inoculação foram liberados cex ca de 500 adultos de Apanieles flavipes (Cam.).

As lagartas de Diatraea saccharalis (Fabr.) que haviam sido colocadas em contato com a cana triturada foram re tiradas dos frascos e colocadas em placas de petri ( \pm 15 laga tas/vez). Posteriormente, uma a uma as lagartas de broca foram retiradas daquelas placas e levadas para o interior da gaiola de "inoculação", procurando-se a fêmea de A. flavipes que $\underline{i}$ mediatamente efetua a postura.

A seguir, estas lagartas foram colocadas indivi dualmente em caixas plästicas e realimentadas com tabletes de dieta de realimentação. Todas as etapas descritas neste item foram realizadas manualmente, sem o auxílio de pinças ou instrumentos semelhantes.

Esta operação foi repetida por mais duas vezes em dias diferentes, conforme o delineamento mencionado no item 3.2 .1 . 
3.2.2.2. Infestação das lagartas de Diatraea saccharalis (Fabr.) com larvas das moscas Metagonistylum minense (Towns.) e Paratheresia claripalpis (Wulp.)

As lagartas de D. saccharalis foram retiradas dos tubos de dieta sendo selecionadas pelo tamanho (15 a $20 \mathrm{~mm}$ ) e pela motilidade.

Essas lagartas foram então colocadas dentro de uma caixa de Petri debaixo de uma lupa e pinceladas com solução fisiológica. Na mesma placa efetuou-se a dissecação de uma fêmea grávida do parasito, retirando-se as larvas de seu abdome e colocando-as em contato com a lagarta. As lagartas foram então acondicionadas individualmente em caixas plásticas de $6 \mathrm{~cm}$ de diametro por $2 \mathrm{~cm}$ de altura e realimentadas con a dieta artificial.

Essa operação foi repetida por mais duas vezes em dias diferentes, perfazendo as 3 fases mencionadas em 3.2.1.

3.2.3. Obtenção do inóculo utilizado nos bioensaios

Lagartas de Diatraea saccharalis (Fabr.) mortas pe10 fungo Metarhizium anisopliae (Metsch.) Sorok foram desin festadas em solução de hinoclorito de sódio a $5 \%+$ espalhante adesivo Agral a 1\% e depois lavadas por duas vezes em água 
destilada esterilizada. Essas lagartas ainda com conídios superficiais foram então raspadas com bisturi esterilizado, e uma porção desses conídios transferidos para placas com. ABD + antibiótico.

Essas placas foram mantidas a $26^{\circ} \mathrm{C}$ por um perío do de \pm 5 dias até à obtenção de uma colônia pura. A partir des sa colônia eram preparadas as placas para produção dos conídios utilizados nos experimentos.

3.2.4. Preparação da suspensão de conídios de Metarhizium anisopliae (Metsch.) Sorok.

Para a preparação da suspensão, a superfície das colônias foram raspadas para obtenção de $0,1 \mathrm{~g}$ de conídios. Es tes for am suspensos em $100 \mathrm{ml}$ de água destilada estéril conten do espalhante adesivo Agral, na proporção de 1 gota/1itro de á gua. A suspensão obtida foi colocada no agitador por um períododo de aproximadamente 2 horas para sua homogeneização.

Em seguida foi realizada a quantificação através da contagem de conídios em uma câmara de Neubauer até a ob tenção da concentração de $10^{7}$ conídios/mi de suspensão.

Para a determinação do nümero de conídios por in divíduo, após a inoculação tomaram-se 20 lagartas ao acaso efetuando-se a lavagem das mesmas em $7 \mathrm{ml}$ de ägua destilada esterilizada. A partir da suspensão obtida realizou-se a contagem dos 
conídios em câmara de Neubauer. A média das contagens foi multiplicada pelo fator 0,35 , obtendo-se assim o número de conídios por indivíduo.

3.2.5. Inoculação das lagartas de Diatraea saccharalis (Fabr.) com o fungo Metarhizium anisopliae (Metsch.) Sorok.

As inoculações das lagartas de broca da cana-de-açücar com o fungo $M$. anisopliae, foram realizadas em 3 fa ses distintas ou sejam: 1,3 e 6 dias após a inoculação com os parasitos.

Para inoculação das 20 lagartas componentes de um tratamento com o patógeno, as mesmas foram retiradas das cai xas plästicas onde eram mantidas após a inoculação com os inse tos parasitos. A seguir foram colocadas em uma câmara de inocu lação telada de $6 \mathrm{~cm}$ de diâmetro por $2 \mathrm{~cm}$ de altura, e imersas na suspensão de conídios previamente quantificada, sendo posteriormente recolocadas nas caixas plásticas e reali mentadas com pedaços de colmo de cana-de-açúcar. Depois foram transferidas para câmaras do tipo BOD e mantidas na temperatura de $26 \pm 0,5^{\circ} \mathrm{C}$ e fotoperíodo de 16 horas.

Os insetos foram observados diariamente, anotan do-se o número de lagartas mortas pelo fungo, nümero de crisălidas, nümero de lagartas mortas por outras causas, nümero de pupas dos 
taquinídeos, massas de Apanteles, além de qualquer outra ocorrência de interesse para o trabalho.

Os parasitos que emergiram como pupas foram acondicionados em caixas plásticas até a emergência dos adultos. As observações foram feitas durante o período de 30 dias.

\subsubsection{Bioemsaios com adultos dos parasitos da broca da cana}

Os dois experimentos relacionados a seguir foram realizados para se determinar a possível aça do $M$. anisopliae sobre os adultos dos parasitos da broca.

3.2.6.1. Experimento II: Inoculação do Metarhizium anisopliae (Metsch.) Sorok. em adultos de Apanteles flavipes (Cam.)

Para se testar a patogenicidade do fungo Metarhizium anisopliae (Metsch.) Sorok. ao braconídeo Apanteles flavipes (Cam.), procedeu-se da seguinte forma:

Placas de cristalização de $10 \mathrm{~cm}$ de diâmetro por $5 \mathrm{~cm}$ de altura foram tratadas com uma suspensão de conídios contendo $10^{7}$ conídios/m1. Depois de secas, uma caixa plástica contendo 2 massas de casulos com mais ou menos 50 parasitos re 
cém-emergidos, foram introduzidas dentro desse recipiente que foi fechado com o plástico Magipac. Os parasitos liberados den tro dessa placa andavam pelas paredes da placa de cristalização entrando em contato com os conídios do fungo, sendo dessa maneira inoculados.

Foram utilizadas 6 dessas placas de cristalização, sendo que as placas I,. II e III correspondiam às temperaturas de 22,26 e $30^{\circ} \mathrm{C}$, respectivamente. As placas IV, $V$ e VI representavam as testemumhas, as quais foram tratadas apenas com ägua esterilizada.

Dentro de cada placa foi colocado um chumaço de algodão molhado com água esterilizada para manter a umidade.

os insetos foram observados diariamente contando-se o número de mortos. Os insetos mortos eram retirados, de sinfestados com solução de hipoclorito a $5 \%$, lavados com água destilada estéril e colocados em placas de Petri contendo meio de cultura $A B D$, para se verificar o possível desenvolvimento do patōgeno.

3.2.6.2. Experimento III: Inoculação do Metarhị zium anisopliae (Metsch.) Sorok. em adultos de Metagonistylum minense (Towns.) e Paratheresia claripalpis (Wulp.)

Para se testar a patogenicidade do fungo Meta- 
rhizium anisopliae sobre os adultos dos dipteros Metagonistylum minense e Paratheresia claripalpis, procedeu-se da seguinte maneira:

Uma tira de papel filtro de $36 \times 16 \mathrm{~cm}$ que foi ba nhada em uma suspensão de conídios, contendo $10^{7}$ conídios $/ \mathrm{mI}$, foi colocada no interior de gaiolas teladas de $13 \mathrm{~cm}$ de diâmetro por $16 \mathrm{~cm}$ de altura, facejado as suas paredes. Dentro dessa gaiola foram soltas cerca de 50 moscas, que entravam em con tato com os conídios aderidos ao papel quando andavam sobre o mesmo.

Foram utilizadas 12 gaiolas teladas, sendo que nas gaiolas I, II e III foram colocados 50 adultos de Metagonistylum em cada uma, e mantidas às temperaturas de 22,26 e $30^{\circ} \mathrm{C}$, respectivamente. As gaiolas IV, V, VI, correspondiam às testemunhas, onde o papel filtro foi banhado apenas com água esterilizada.

Da mesma forma, nas gaiolas VII, VIII e IX foram colocados cerca de 50 adultos de Paratheresia em cada uma, e mantidas às temperaturas de 22,26 e $30^{\circ} \mathrm{C}$; sendo que as gaio las $X, X I$ e XII representaram as testemunhas desse grupo.

Essas gaiolas contendo os insetos foram revisadas diariamente, anotando-se o número de insetos mortos. Estes eram retirados, desinfestados com a solução de hipoclorito, la vados com água destilada estéril e colocados em placa de Petri contendo meio de cultura $A B D$, para se verificar o possível desenvolvimento do patógeno. 


\subsubsection{Bioensaios com pupas dos parasitos da broca da cana}

Os experimentos relacionados a seguir foram rea lizados para se determinar a possível patogenicidade do M. an $\underline{i}$ sopliae sobre pupas de parasitos da broca da cana.

3.2.7.1. Experimento IV: Inoculação do Metarhizium anisopliae (Metsch.) Sorok. em mas sas de Apanteles blavipes (Cam.)

Duas massas de casulos de Apanteles Glavipes (Cam.) contendo aproximadamente 50 pupas do parasito foram banhadas com uma suspensão de conídios do fungo, contendo $10^{7}$ conídios/ml. As massas após esse tratamento, foram colocadas sobre papel filtro visando absorver o excesso da suspensão de conidios.

Essas massas foram transferidas para uma placa de cristalização de $10 \mathrm{~cm}$ de diâmetro por $5 \mathrm{~cm}$ de altura e pos teriormente mantidas em câmaras BOD sob as temperaturas de 22 , 26 e $30^{\circ} \mathrm{C}$ até a emergência dos micro-himenópteros adultos.

Foram utilizadas no experimento 6 placas de cris talização, sendo que a placa $\mathbf{A}$, recebeu duas massas traíadas e foi colocada à temperatura de $22^{\circ} \mathrm{C}$, juntamente com a placa a que recebeu duas massas tratadas com água esterilizada, ao 
invês da suspensão de conídios, representando assim a testemu nha.

Da mesma forma, a placa $\mathbf{B}$, que recebeu as massas tratadas foi colocada juntamente com a placa b que continha massas não tratadas à temperatura de $26^{\circ} \mathrm{C}$ e a placa C contendo massas tratadas foi colocada juntamente com a placa $\mathfrak{c}$, com massas não tratadas à temperatura de $30^{\circ} \mathrm{C}$.

Após a morte dos insetos estes foram desinfesta dos com solução de hipoclorito a $5 \%$, lavados por duas vezes em āgua esterilizada sendo posteriormente transferidos para placas de Petri contendo meio de cultura $A B D$, para se verificar o possive1 desenvolvimento do patógeno.

3.2.7.2. Experimento V: Inoculação do Metarhizium anisopliae (Metsch.) Sorok. em pupas de Metagonistylum minense (Towns.) e Paratheresia claripalpis. (Wulp.)

Para se testar a patogenicidade do Metarhizium anisopliae sobre pupas dos dípteros parasitos, procedeu-se da seguinte forma:

Foram tratadas com uma suspensão contendo $10^{7}$ conídios de Metarhizium anisopliae, 50 pupas de cada espécie de mosca. Após o tratamento as pupas foram transferidas para gaiolas teladas. 
Foram utilizadas 12 gaiolas, sendo que em cada uma das gaiolas A, B, C, foram colocadas 50 pupas de Metagonis tylum minense inoculadas com Metarhizium anisopliae. Nas gaiolas a, b, c, foram colocadas outras 50 pupas da mesma espécie não inoculadas, correspondendo pela ordem às testemunhas. Esses 3 grupos de gaiolas (A,a; B,b; C, C) foram mantidos às temperaturas de 22,26 e $30^{\circ} \mathrm{C}$, respectivamente.

Da mesma forma, em cada uma das gaiolas D, E, F, foram colocadas 50 pupas de Paratheresia claripalpis inoculadas com a mesma suspensão de conídios e nas gaiolas d, e, $f$, foram colocadas outras 50 pupas da mesma espécie não inoculadas, correspondendo pela ordem as testemunhas.

As condições pós-inoculação foram as mesmas jä referidas para $M$. minense.

A medida en que os adultos morriam, os mesmos e ram colocados em placas de Petri com $A B D$ + antibiótico para se verificar a possível causa da morte.

os dados foram referidos em porcentagem de mortalidade. 


\section{RESULTADOS E DISCUSSÃO}

\subsection{EXPERIMENTO I: INTERACÃO ENTRE OS PRINCIPAIS PARASITOS DA BROCA DA CANA-DE-ACÚCAR Díatraea saccharalis (FABR,) E O FUNGO Wetarhizium anisopliae (METSCH.) SOROK.}

Os resultados do experimento de competição entre os parasitos da Diatraea saccharalis (Fabr.) e o fungo Metarhizium anisopliae (Metsch.) Sorok., desenvolvido nas temperaturas de 22,26 e $30^{\circ} \mathrm{C}$ estão relacionados nas Tabelas de 1 a 23, sendo as representações gräficas apresentadas nas Figuras de 3 a 8 .

Na Tabe1a 1 encontram-se os dados de porcentagem média de mortalidade da praga devida aos diferentes tratamentos. A Tabela 2 refere-se à análise estatística do experimento. 
Tabela 1 - Porcentagem média de mortalidade de lagartas de $D$. saccharalis, submetidas ao tratamento com M. anisopliae, inoculadas com os parasitos isoladamente e pela interação de ambos os agentes, em diferentes temperaturas.

\begin{tabular}{|c|c|c|c|c|}
\hline \multirow[t]{2}{*}{ Fases } & \multirow[t]{2}{*}{ Tratamentos } & \multicolumn{3}{|c|}{ Temperaturas } \\
\hline & & $22^{\circ} \mathrm{C}$ & $26^{\circ} \mathrm{C}$ & $30^{\circ} \mathrm{C}$ \\
\hline \multirow{8}{*}{$\begin{array}{l}1 \text { a } \\
\text { (fungo i- } \\
\text { noculado } \\
1 \text { dia a- } \\
\text { pós a ino } \\
\text { culação } \\
\text { do parasi } \\
\text { to) }\end{array}$} & $C_{1}$ (normal) & 0 & 0 & 0 \\
\hline & $\mathrm{C}_{2}$. (Metarhizium) & 48,33 & 58,33 & 18,33 \\
\hline & $\mathrm{C}_{3}$ (Apanteles) & 63,33 & 67,50 & 40,00 \\
\hline & $\mathrm{C}_{4}(\mathrm{Ap}+$ M.a. $)$ & 75,00 & 80,83 & 48,33 \\
\hline & $\mathrm{C}_{5}$ (Metagonistylum) & 63,33 & 55,83 & 46,67 \\
\hline & $\mathrm{C}_{6}(\mathrm{Meta}+$ M.a. $)$ & 83,33 , & 80,83 & 51,67 \\
\hline & $C_{7}$ (Paratheresia) & 78,33 & 81,67 & 53,33 \\
\hline & $\mathrm{C}_{8}$ (Para + M.a. $)$ & 81,67 & 80,83 & 58,33 \\
\hline \multirow{8}{*}{$\begin{array}{l}2 \text { a } \\
\text { (fungo i- } \\
\text { noculado } \\
3 \text { dias a- } \\
\text { pos a ino } \\
\text { culação } \\
\text { dos para- } \\
\text { sitos) }\end{array}$} & $\mathrm{C}_{1}$ (normal) & 0 & 0 & 0 \\
\hline & $\mathrm{C}_{2}$ (Metarhizium) & 53,33 & 70,00 & 23,33 \\
\hline & $\mathrm{C}_{3}$ (Apanteles) & 55,00 & 75,83 & 48,33 \\
\hline & $\mathrm{C}_{4}$ (Ap. + M.a.) & 61,67 & 87,50 & 61,67 \\
\hline & $\mathrm{C}_{5}$ (Metagonistylum) & 61,67 & 53,33 & 68,33 \\
\hline & $\mathrm{C}_{6}($ Meta + M.a. $)$ & 73,33 & 68,33 & 61,67 \\
\hline & $C_{7}$ (Paratheresia) & 80,00 & 78,33 & 60,00 \\
\hline & $\mathrm{C}_{8}$ (Para + M.a.) & 85,00 & 82,50 & 53,33 \\
\hline \multirow{8}{*}{$\begin{array}{l}3 \text { ă } \\
\text { (fungo i- } \\
\text { noculado } \\
6 \text { dias a- } \\
\text { pós a ino } \\
\text { culação } \\
\text { dos para- } \\
\text { sitos) }\end{array}$} & $\mathrm{C}_{1}$ (normal) & 0 & 0 & 0 \\
\hline & $\mathrm{C}_{2}$ (Metarhizium) & 53,33 & 55,00 & 25,00 \\
\hline & $\mathrm{C}_{3}$ (Apanteles) & 78,33 & 79,17 & 65,00 \\
\hline & $\mathrm{C}_{4}$ (Ap. + M.a.) & 76,67 & 85,83 & 56,67 \\
\hline & $\mathrm{C}_{5}$ (Metagonistylum) & 71,67 & 51,67 & 58,33 \\
\hline & $\mathrm{C}_{6}$ (Meta + M.a.) & 76,67 & 71,67 & 48,33 \\
\hline & $C_{7}$ (Paratheresia) & 73,33 & 80,83 & 66,67 \\
\hline & $\mathrm{C}_{8}($ Para + M.a. $)$ & 76,67 & 85,00 & 73,33 \\
\hline
\end{tabular}

$\mathrm{Ap}=$ Apanteles M.a.=Metarhiziumi anisopliae Meta=Metagonistylum Para $=$ Paratheresia 
Tabela 2 - Resultados da análise estatística para porcentagem média de mor talidade de lagartas de $D$. saccharalis submetidas ao tratamento com M. anisopliae, inoculadas com os parasitos e pela interação de ambos os agentes em diferentes temperaturas (dados transformados para arco seno).

\begin{tabular}{|c|c|c|c|}
\hline & \multicolumn{3}{|c|}{ Temperaturas } \\
\hline & $22^{\circ} \mathrm{C}$ & $26^{\circ} \mathrm{C}$ & $30^{\circ} \mathrm{C}$ \\
\hline Teste F p/condições & $4,32^{* *}$ & $9,57^{* *}$ & $7,15^{* *}$ \\
\hline Teste $\mathrm{F}$ p/fases & $0,04 \mathrm{NS}$ & $0,07 \mathrm{NS}$ & $2,86 \mathrm{NS}$ \\
\hline Teste F p/interações & $0,57 \mathrm{NS}$ & $0,85 \mathrm{NS}$ & $0,64 \mathrm{NS}$ \\
\hline C.V. & $17,073400^{\circ}$ & $17,500400^{\circ}$ & $20,631900 \%$ \\
\hline Q.M. Res. & 99,13790 & 110,31700 & 90,57310 \\
\hline \multicolumn{4}{|l|}{ Mëdias das condições } \\
\hline Condição 2 & $45,96310 \mathrm{~B}$ & $52,09710 \mathrm{BC}$ & $27,57740 \mathrm{~B}$ \\
\hline Condição 3 & $54,42270 \mathrm{AB}$ & $60,85980 \mathrm{AB}$ & $45,86060 \mathrm{~A}$ \\
\hline Condição 4 & $62,43380 \mathrm{~A}$ & $68,01600 \mathrm{~A}$ & $48,68720 \mathrm{~A}$ \\
\hline Condição 5 & $54,57650 \mathrm{AB}$ & $47,44770 \mathrm{C}$ & $49,75580 \mathrm{~A}$ \\
\hline Condição 6 & $62,43380 \mathrm{~A}$ & $60,38910 \mathrm{AB}$ & $47,31440 \mathrm{~A}$ \\
\hline Condição 7 & $63,47990 \mathrm{~A}$ & $64,49360 \mathrm{~A}$ & $51,11700 \mathrm{~A}$ \\
\hline Condição 8 & $64,91290 \mathrm{~A}$ & $66,81560 \mathrm{~A}$ & $52,58010 \mathrm{~A}$ \\
\hline$\Delta(5 \%)$ & 14,570100 & 10,554400 & 13,926500 \\
\hline \multicolumn{4}{|l|}{ Mídias de Fases } \\
\hline Fase 1 ( 1 dia após) & 58,01140 & 59,86370 & 42,19840 \\
\hline Fase 2 ( 3 dias apös) & 58,10490 & 60,48840 & 47,21340 \\
\hline Fase 3 ( 6 dias após) & 58,83620 & 59,69890 & 48,97070 \\
\hline
\end{tabular}


Pode-se verificar através da Tabela 1 que o com portamento do fungo ou dos parasitos foi semelhante nas três tem peraturas estudadas, ocorrendo na maioria dos casos, uma interação positiva quando os dois agentes foram aplicados juntos. Isto é, observou-se um aumento na porcentagem de mortalida de da praga nos tratamentos em que se aplicou parasitot fungo, quando comparados com os tratamentos em que esses agentes foram aplicados isoladamente. Esses resultados poderiam ser explicados com o trabalho de EL-SUFTY e FürER (1981), os qua is atribuiram o aunento da mortalidade de lagartas de $P$. brass $i$ cae pela interação de um parasito e un patógeno, aos efeitos patofisiológicos das larvas do parasito sobre a cutícula do hos pedeiro, facilitando assim a penetração do microrganismo.

A interação positiva foi mais evidente nas temperaturas de 22 e $26^{\circ} \mathrm{C}$ (Figuras 3,4 e 5 ). Na temperatura de $30^{\circ} \mathrm{C}$, foi observada, principalmente, para a primeira fase. A inversão de resultados ocorrida na 2 a e 3 a fases, pode ter sido ocasionada por uma maior incidência de contaminação havida nessa temperatura, principalmente nos tratamentos com inocula ção de fungo + parasito, devido a uma maior manipulação do material e melhores condicões para desenvolvimento de contaminan tes representados por Aspergillus sp. conforme jä foi relatado por ALVES et alii $(1984 a, b)$. Também, nessas condições ocorre o desenvolvimento de um grande nümero de bactérias sapröfitas. 


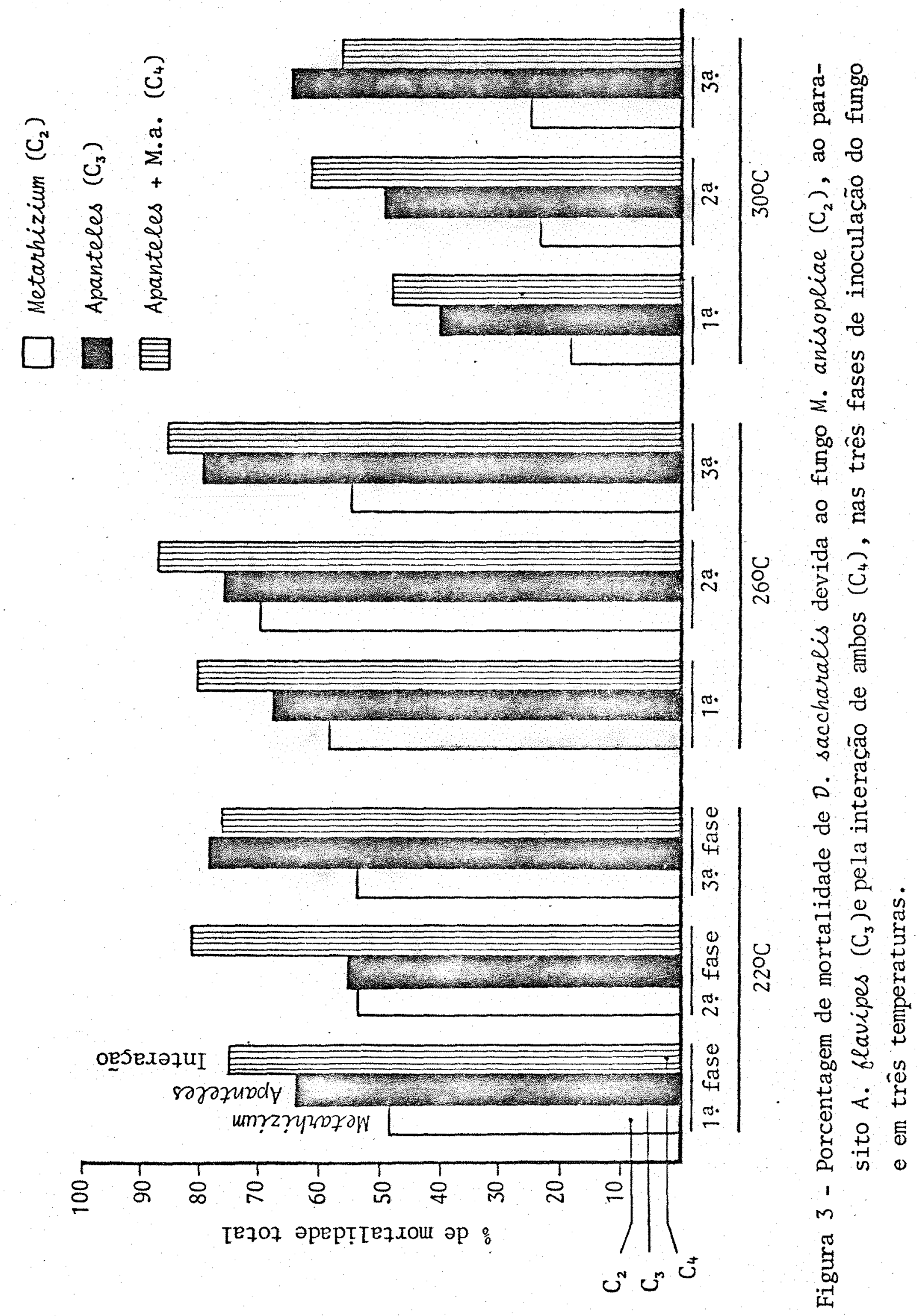



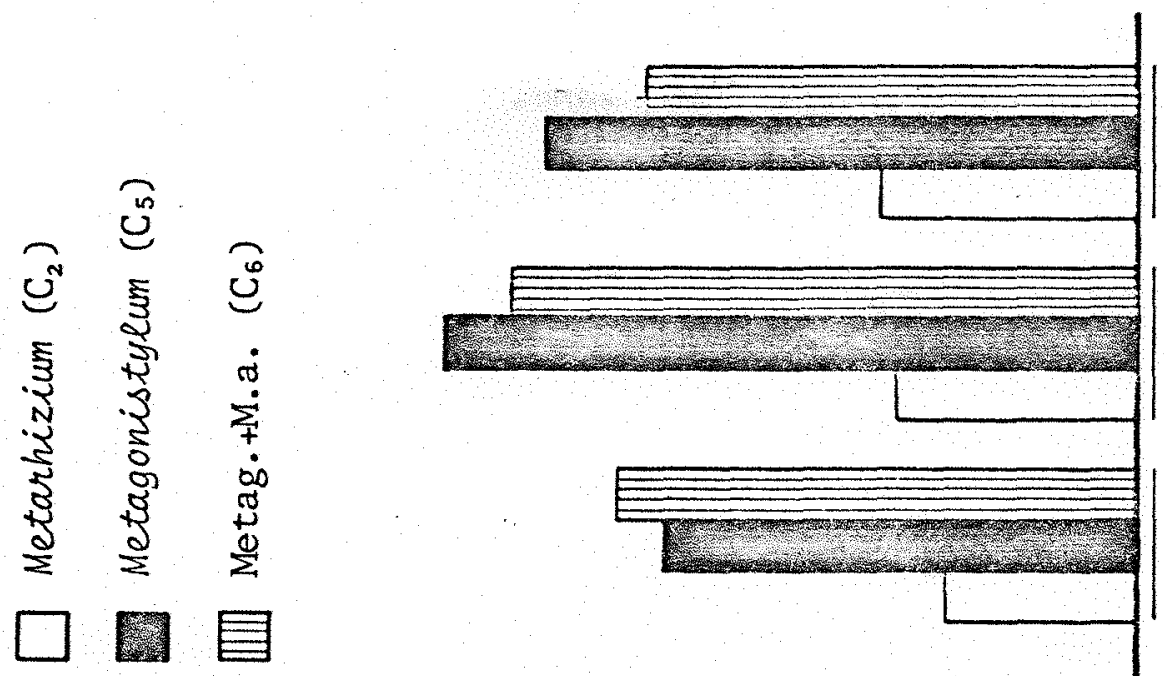

\section{$\stackrel{\pi}{\sim}$
$\stackrel{\pi}{\sim}$
$\sim$}

$\therefore$

竞 $\frac{1}{8}$

$\stackrel{0}{\circ}$

敢

in

है थ

से

\&

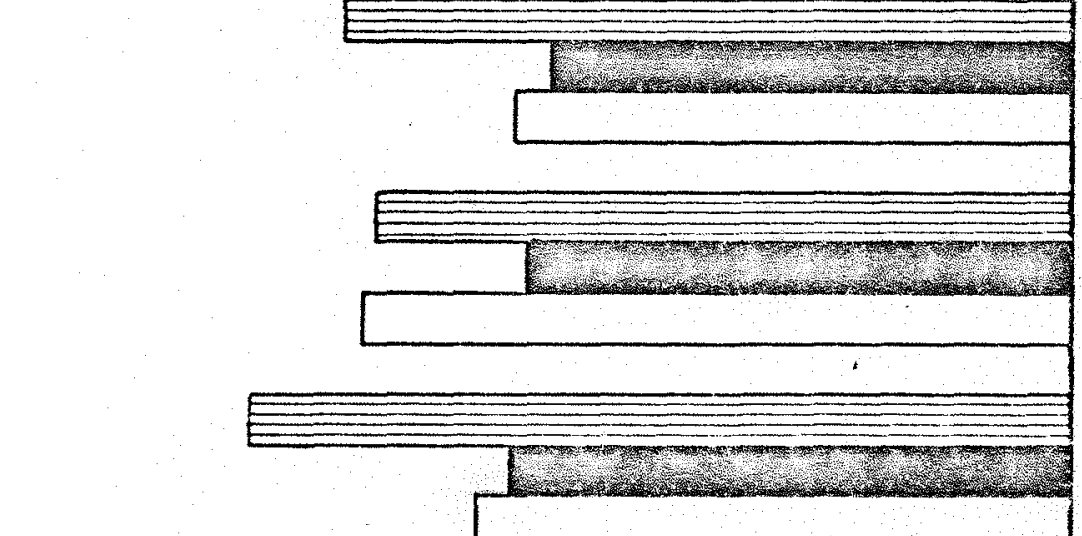

(3.

๓2

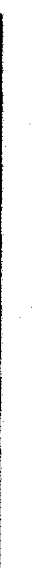
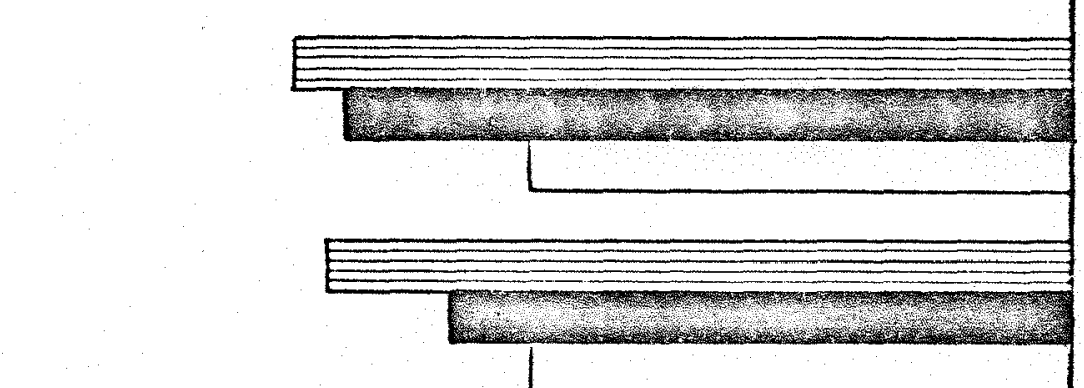

opSexә7uI

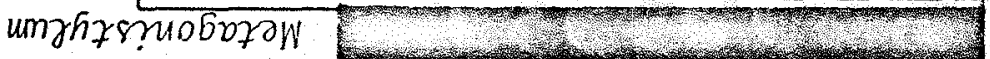
umrzryzo7oW

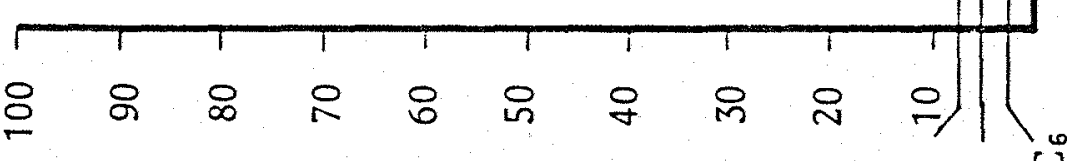

[е707 әрерт[е]xоut әр:

$\tilde{u}$

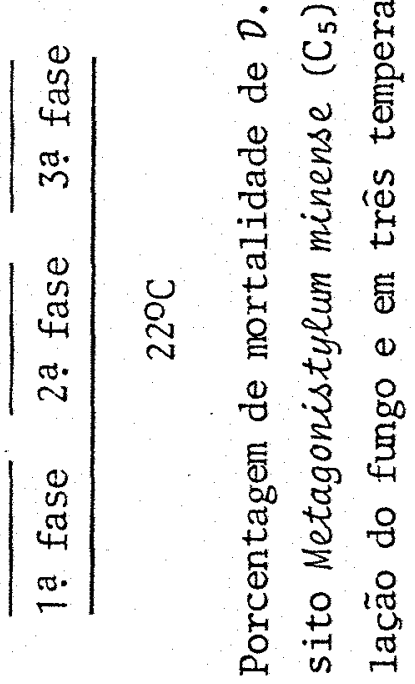

1

$\forall$

苧

ir 
.47 .

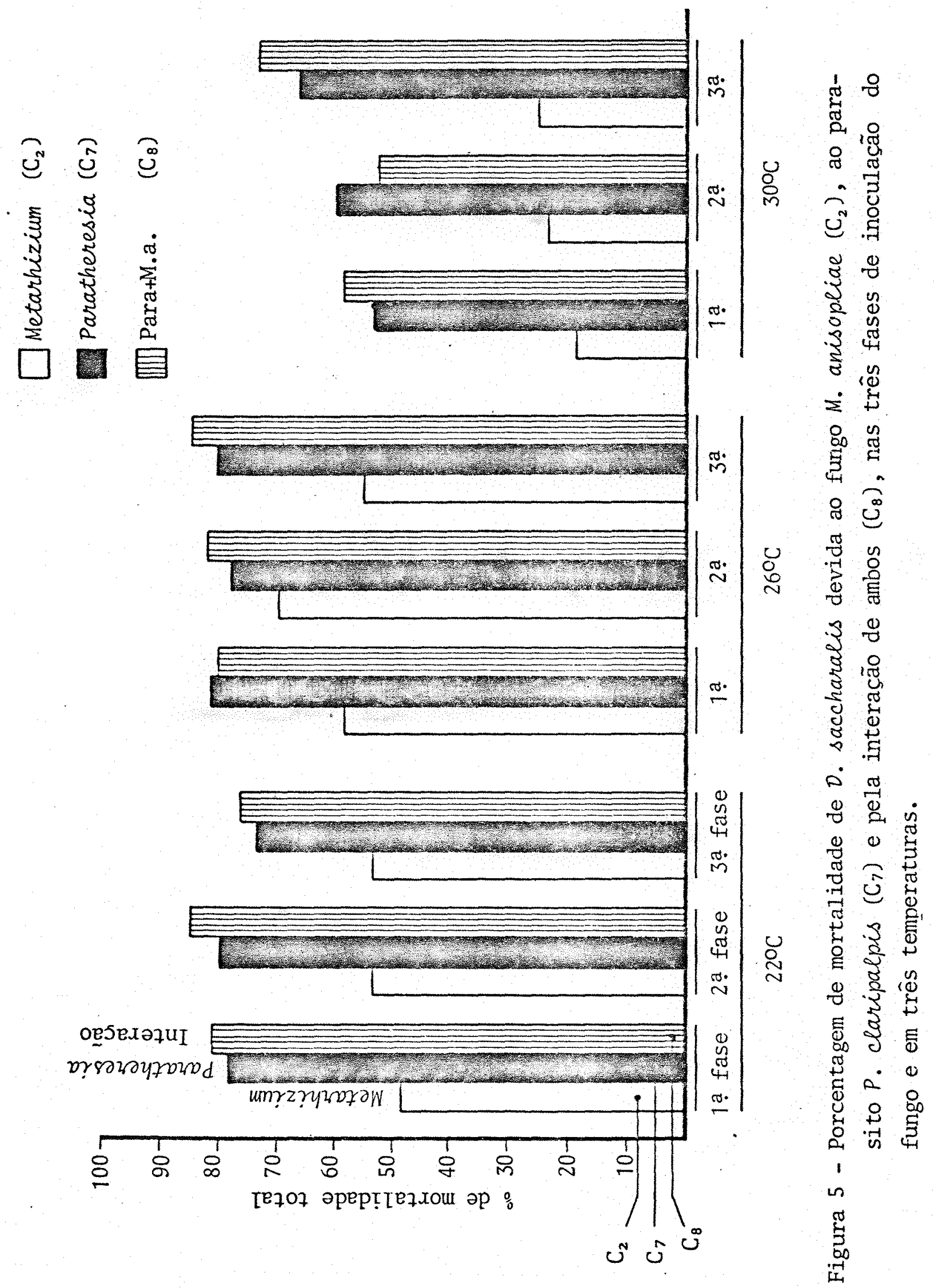


Ainda, com relação aos tratamentos onde os dois agentes foram inoculados conjuntamente, nas diferentes fases de aplicação do fungo a análise estatística não acusou nenhuma diferença entre elas (Tabela 2). No entanto, através das Tabelas 3,4 e 5, onde se pode observar o efeito de cada agente $i$ soladamente, verifica-se que, de maneira geral, apesar da inte ração ser positiva, o fungo chegou a afetar o desenvolvimento dos parasitos quanto inoculado um dia após o início do parasitismo (Figuras 6, 7 e 8). Esses resultados concordam com os en contrados por KING e BELL (1978), os quais trabalharam com o fungo Nomuraea rileyi e o parasito Microplitis croceipes em Heliothis zea.

Da mesma forma, IBARAGON e BROOKS (1974) e BEEGLE e OATMAN (1975), estudando a interação entre o NPV de Heliothis e NPV de Trichoplusia, com relação aos parasitos Campo letis sonorensis e Hyposoter exiguae, respectivamente, verificaram que os vírus podem reduzir a sobrevivência dos parasitos, quando inoculados nas lagartas, logo após o parasitismo.

Para o A. Glavipes pode-se observar que na temperatura de $26^{\circ} \mathrm{C}$ o fungo provocou mortalidade equivalente ao parasito quando inoculado três dias após a instalação deste pa rasito. Os resultados concordam de um modo geral com KAYA (1978) que relacionou o estágio de desenvolvimento do parasitóide den tro do hospedeiro por ocasião da infecção por um nematóide com a porcentagem de casulos normais produzidos pelo parasito. 
Tabela 3 - Mortalidade total de lagartas de 0 . saccharalis do Experimento $I$, devida à ação de A. flavipes, do M. anisopliae e pela ação de ambos os agentes nas temperaturas de 22,26 e $30^{\circ} \mathrm{C}$.

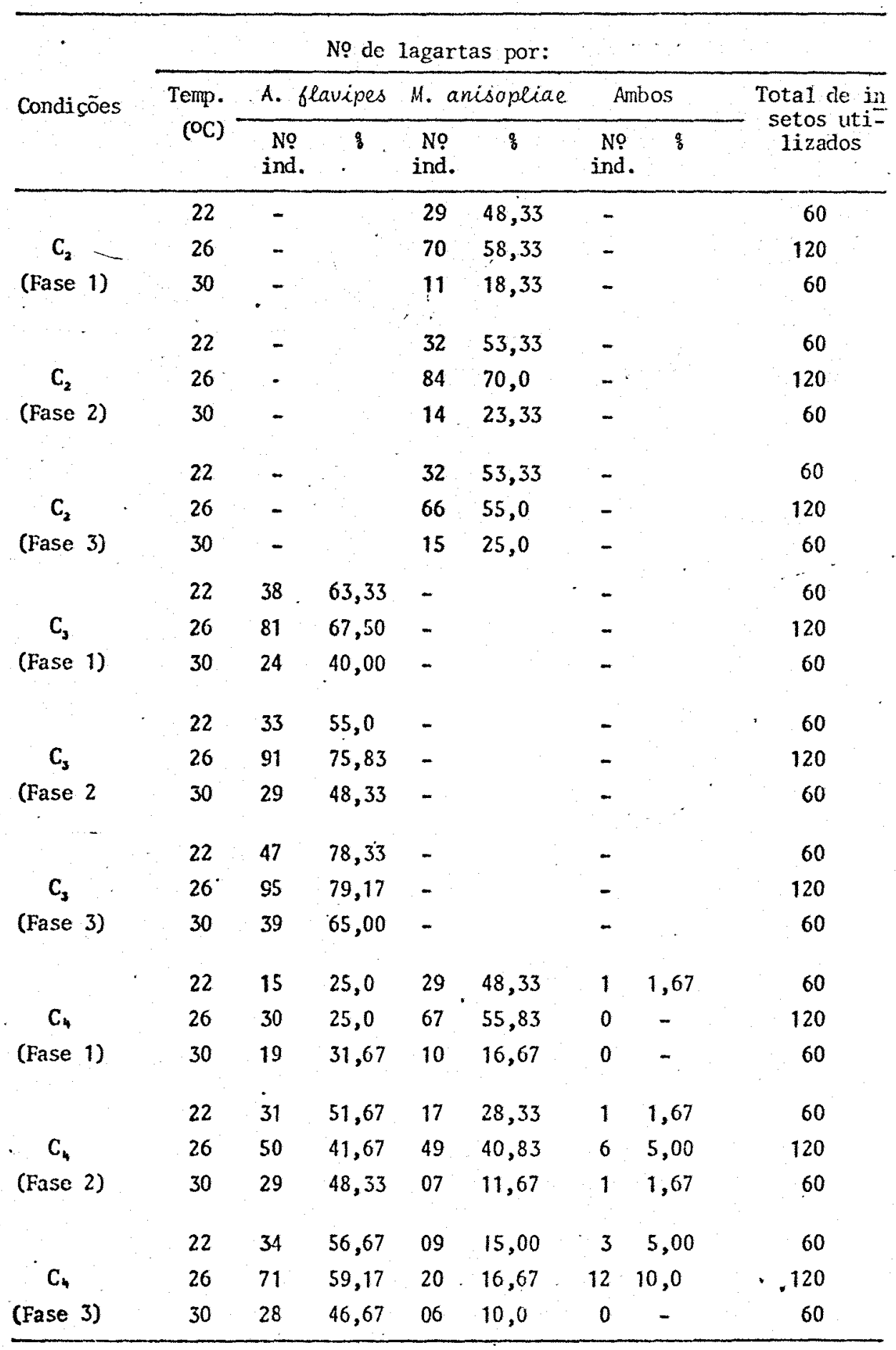


Tabela 4 - Mortalidade total de lagartas de D. saccharalis do Experimento I, devida à ação de Metagonistylum minense, do Metarhizium anisopliae e pela ação de ambos os agentes nas temperaturas de 22 , 26 e $30^{\circ} \mathrm{C}$.

\begin{tabular}{|c|c|c|c|c|c|c|c|c|}
\hline \multirow{3}{*}{ Condiçōes } & \multirow{3}{*}{$\begin{array}{l}\text { Temp. } \\
\left.{ }^{\circ} \mathrm{C}\right)\end{array}$} & \multicolumn{6}{|c|}{ № de lagartas mortas por: } & \multirow{3}{*}{$\begin{array}{l}\text { Total } \\
\text { de insetos } \\
\text { utilizados }\end{array}$} \\
\hline & & \multicolumn{2}{|c|}{ M. minense } & \multicolumn{2}{|c|}{ M: anisopliae } & \multicolumn{2}{|c|}{ Anbos } & \\
\hline & & $\begin{array}{l}\text { Nọ } \\
\text { ind. }\end{array}$ & 8 & $\begin{array}{l}\text { No } \\
\text { ind. }\end{array}$ & \& & $\begin{array}{c}\text { No } \\
\text { ind. }\end{array}$ & 8 & \\
\hline & 22 & - & & 29 & 48,33 & - & & 60 \\
\hline$C_{2}$ & 26 & - & & 70 & 58,33 & - & & 120 \\
\hline \multirow[t]{2}{*}{ (Fase 1) } & 30 & - & & 11 & 18,33 & - & & 60 \\
\hline & 22 & - & & 32 & 53,33 & - & & 60 \\
\hline $\mathrm{C}_{2}$ & 26 & $=$ & & 84 & 70,00 & - & & 120 \\
\hline \multirow[t]{2}{*}{ (Fase 2) } & 30 & - & & 14 & 23,33 & - & & 60 \\
\hline & 22 & - & & 32 & 53,33 & - & & 60 \\
\hline $\mathrm{C}_{2}$ & 26 & - & & 66 & 55,0 & - & & 120 \\
\hline \multirow[t]{2}{*}{ (Fase 3) } & 30 & - & & 15 & 25,0 & - & & 60 \\
\hline & 22 & 38 & 63,33 & - & & - & & 60 \\
\hline$C_{5}$ & 26 & 67 & 55,83 & - & & - & & 120 \\
\hline \multirow[t]{2}{*}{ (Fạse 1) } & 30 & 28 & 46,67 & - & & - & & 60 \\
\hline & 22 & 37 & 61,67 & - & . & - & . & 60 \\
\hline $\mathrm{C}_{5}$ & 26 & 64 & 53,33 & - & & - & & 120 \\
\hline \multirow[t]{2}{*}{ (Fase 2) } & 30 & 41 & 68,33 & - & & $\cdots$ & & 60 \\
\hline & 22 & 43 & 71,67 & - & & - & & 60 \\
\hline$c_{5}$ & 26 & 62 & 51,67 & - & & $=$ & & 120 \\
\hline \multirow[t]{2}{*}{ (Fase 3). } & 30 & 35 & 58,33 & - & & - & & 60 \\
\hline & 22 & 34 & 56,67 & 16 & 26,67 & 0 & - & 60 \\
\hline$C_{6}$ & 26 & 48 & 40,00 & 48 & 40,00 . & 1 & 0,83 & 120 \\
\hline \multirow[t]{2}{*}{ (Fase 1) } & 30 & 24 & 40,00 & 2 & 11,67 & 0 & - & 60 \\
\hline & 22 & 38 & 63,33 & 6 & 10,00 & 0 & - & 60 \\
\hline$C_{5}$ & 26 & 67 & 55,83 & 12 & 10,00 & 3 & 2,50 & 120 \\
\hline \multirow[t]{2}{*}{ (Fase 2) } & 30 & 34 & 56,67 & 3 & 5,00 & 0 & - & 60 \\
\hline & 22 & 44 & 73,33 & 2 & 3,33 & 0 & - & 60 \\
\hline $\mathrm{C}_{6}$ & 26 & 66 & 55,00 & 19 & 15,83 & 1 & 0,83 & 120 \\
\hline (Fase 3) & 30 & 25 & 41,67 & 4 & 6,67 & 0 & - & 60 \\
\hline
\end{tabular}


Tabela 5 - Mortalidade total de lagartas de 0 . saccharalis do Experimento $I$, devida à ação de $P$. Claripalpis, do $M$. anisopliae e pela ação de ambos os agentes nas temperaturas de 22,26 e $30^{\circ} \mathrm{C}$.

\begin{tabular}{|c|c|c|c|c|c|c|c|c|}
\hline \multirow{3}{*}{$\begin{array}{l}\text { Condiçōes } \\
\text {. }\end{array}$} & \multirow{3}{*}{$\begin{array}{l}\text { Temp. } \\
\left({ }^{\circ} \mathrm{C}\right)\end{array}$} & \multicolumn{6}{|c|}{ № de lagartas mortas por: } & \multirow{3}{*}{$\begin{array}{l}\text { Total de } \\
\text { insetos } \\
\text { utiliza- } \\
\text { dos }\end{array}$} \\
\hline & & \multicolumn{2}{|c|}{ P. claripalpis } & \multicolumn{2}{|c|}{ M. anisopliae } & \multicolumn{2}{|c|}{ Ambos } & \\
\hline & & $\begin{array}{c}\text { No } \\
\text { ind. }\end{array}$ & $\frac{9}{8}$ & $\begin{array}{l}\text { No } \\
\text { ind. }\end{array}$ & : & $\begin{array}{l}\text { No } \\
\text { ind. }\end{array}$ & 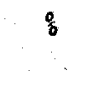 & \\
\hline & 22 & - & . & 29 & 48,33 & - & & 60 \\
\hline $\mathrm{C}_{2}$ & 26 & - & & 70 & 58,33 & - & & 120 \\
\hline \multirow[t]{2}{*}{ (Fase 1) } & 30 & 7 & & 11 & 18,33 & - & & 60 \\
\hline & 22 & - & & 32 & 53,33 & - & & 60 \\
\hline$c_{2}$ & 26 & - & & 84 & 70,00 & - & & 120 \\
\hline \multirow[t]{2}{*}{ (Fase 2) } & 30 & - & & 14 & 23,33 & - & & 60 \\
\hline & 22 & - & & 32 & 53,33 & - & & 60 \\
\hline$C_{2}$ & 26 & - & & 66 & 55,00 & - & & 120 \\
\hline \multirow[t]{2}{*}{ (Fase 3) } & 30 & - & & 15 & 25,00 & - & & 60 \\
\hline & 22 & 47 & 78,33 & - & & - & & 60 \\
\hline $\mathrm{C}_{7}$ & 26 & 98 & 81,67 & - & & - & & 120 \\
\hline \multirow[t]{2}{*}{ (Fase 1) } & 30 & 32 & 53,33 & - & & - & & 60 \\
\hline & 22 & 48 & 80,00 & - & & - & & 60 \\
\hline $\mathrm{C}_{7}$ & 26 & 94 & 78,33 & - & . & - & & 120 \\
\hline \multirow[t]{2}{*}{ (Fase 2) } & 30 & 36 & 60,00 & - & & - & & 60 \\
\hline & 22 & 44 & 73,33 & - & & - & & 60 \\
\hline$C_{7}$ & 26 & 97 & 80,83 & - & & - & & 120 \\
\hline \multirow[t]{2}{*}{ (Fase 3) } & 30 & 40 & 66,67 & - & & - & & 60 \\
\hline & 22 & 44 & 73,33 & 4 & 6,67 & 1 & 1,67 & 60 \\
\hline$C_{B}$ & 26 & 62 & 51,67 & 34 & 28,33 & 1 & 0,83 & 120 \\
\hline \multirow[t]{2}{*}{ (Fase 1) } & 30 & 29 & 48,33 & 5 & 8,33 & 1 & 1,67 & 60 \\
\hline & 22 & 50 & 83,33 & 1 & 1,67 & 0 & - & 60 \\
\hline $\mathrm{C}_{\mathrm{a}}$ & 26 & 86 & 71,67 & 13 & 10,83 & 0 & - & 120 \\
\hline \multirow[t]{2}{*}{ (Fase 2) } & 30 & 29 & 48,33 & 3 & 5,00 & 0 : & - & 60 \\
\hline & 22 & 44 & 73,33 & 2 & 3,33 & 0 & - & 60 \\
\hline$C_{8}$ & 26 & 93 & 77,50 & 8 & 6,67 & 1 & 0,83 & 120 \\
\hline (Fase 3) & 30 & 43 & 71,67 & 1 & 1,67 & 0 & - & 60 \\
\hline
\end{tabular}



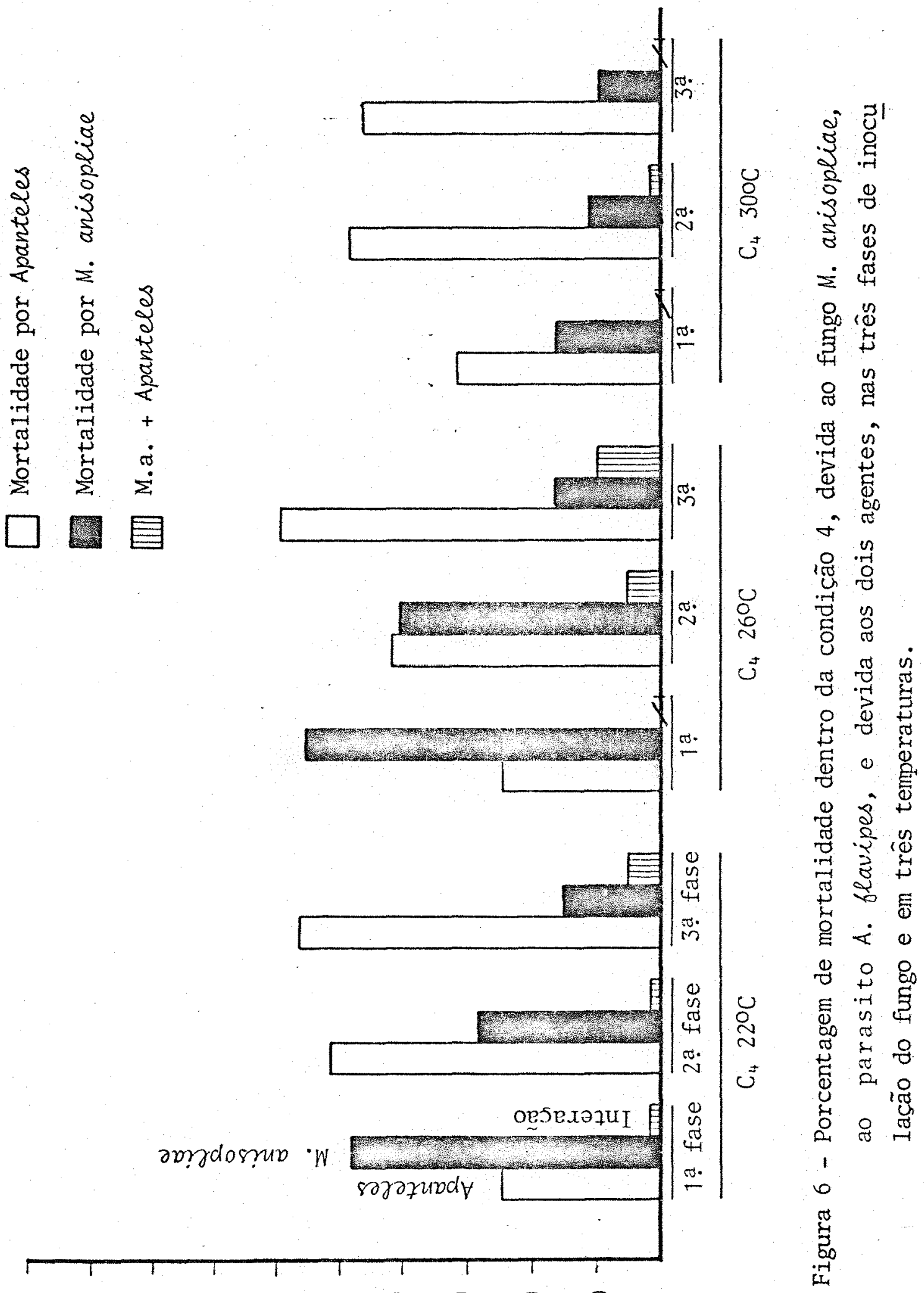
.53.

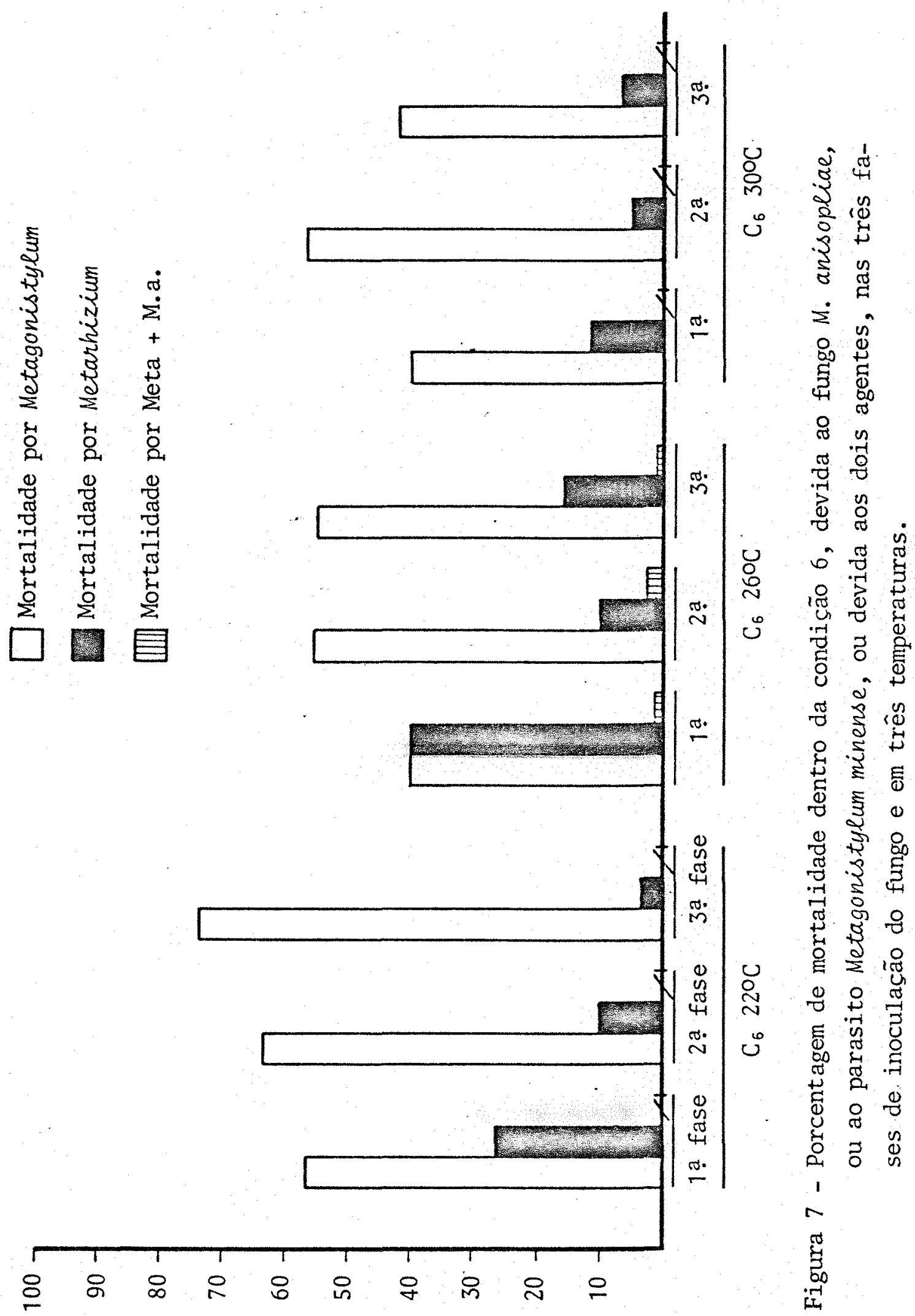

әрертโедтош әр : 
.54 .

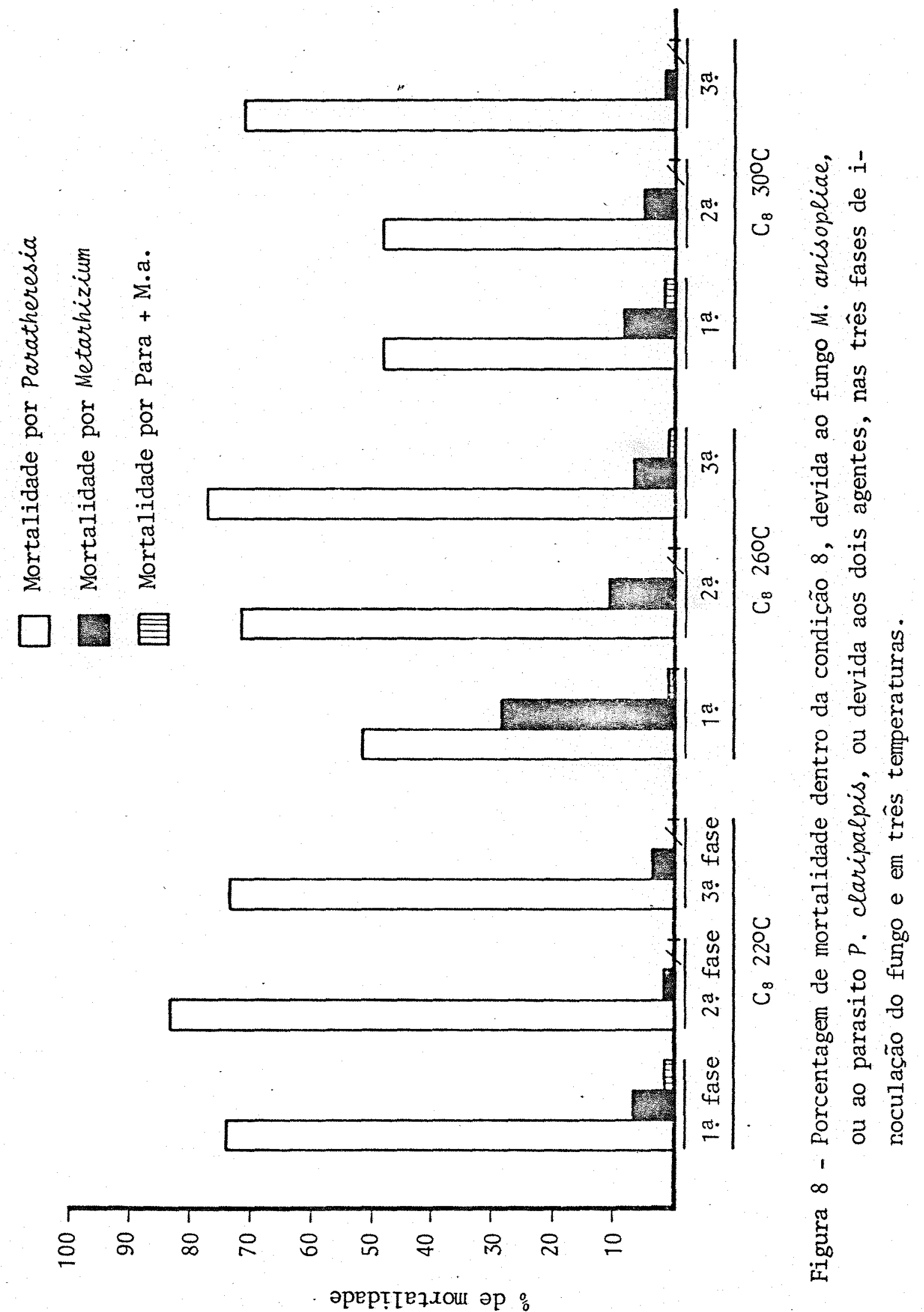


Entre os três parasitos, o taquinídeo $P$. clari palpis mostrou-se o menos afetado na interação com $\circ M$. anisopliae. Este fato é bastante interessante, una vez que $P$. clari palpis é o parasito que apresenta o maior período 1arval, estando assim, teoricamente, mais sujeito aos efeitos deletérios da interação, já que estes, não derivam de uma infecção direta dos parasitos pelo fungo e sim em decorrência da competição pe 1o alimento. Dessa maneira, um hospedeiro infectado parece ser inadequado ao desenvolvimento do parasito, como já foi relatado por BEEGLE e OATMAN (1975) e constatado no presente estudo de maneira significativa somente nara o parasito A. blavipes. Ainda nas Tabelas 3,4 e 5 , verifica-se que, apesar do parasito ter completado seu desenvolvimento na lagarta hospedeira, em alguns casos, ela também mostrou sintomas de infecção por Metarhizium, como o observado por SMITH et alii (1976) em lagartas de Heliothis parasitadas por M. croceipes e N. rileyi.

As Tabelas 6 a 23 referem-se aos efeitos biológicos no desenvolvimento dos parasitos em hospedeiros infecta dos pelo patógeno.

Nas Tabelas 6 a 11 pode-se observar que, nas três temperaturas estudadas o período de desenvolvimento dos parasi tos dentro do hospedeiro, não foi afetado pela presença do fun go M. anisopliae na mesma lagarta, o que foi confirmado pela a nälise estatistica. 
Tabela 8 - Duração mëdia da fase larval de A. Glavipes em lagartas de $D$. saccharalis infectadas e não infectadas por $M$. anisopliae nas temperaturas de 22,26 e $30{ }^{\circ} \mathrm{C}$

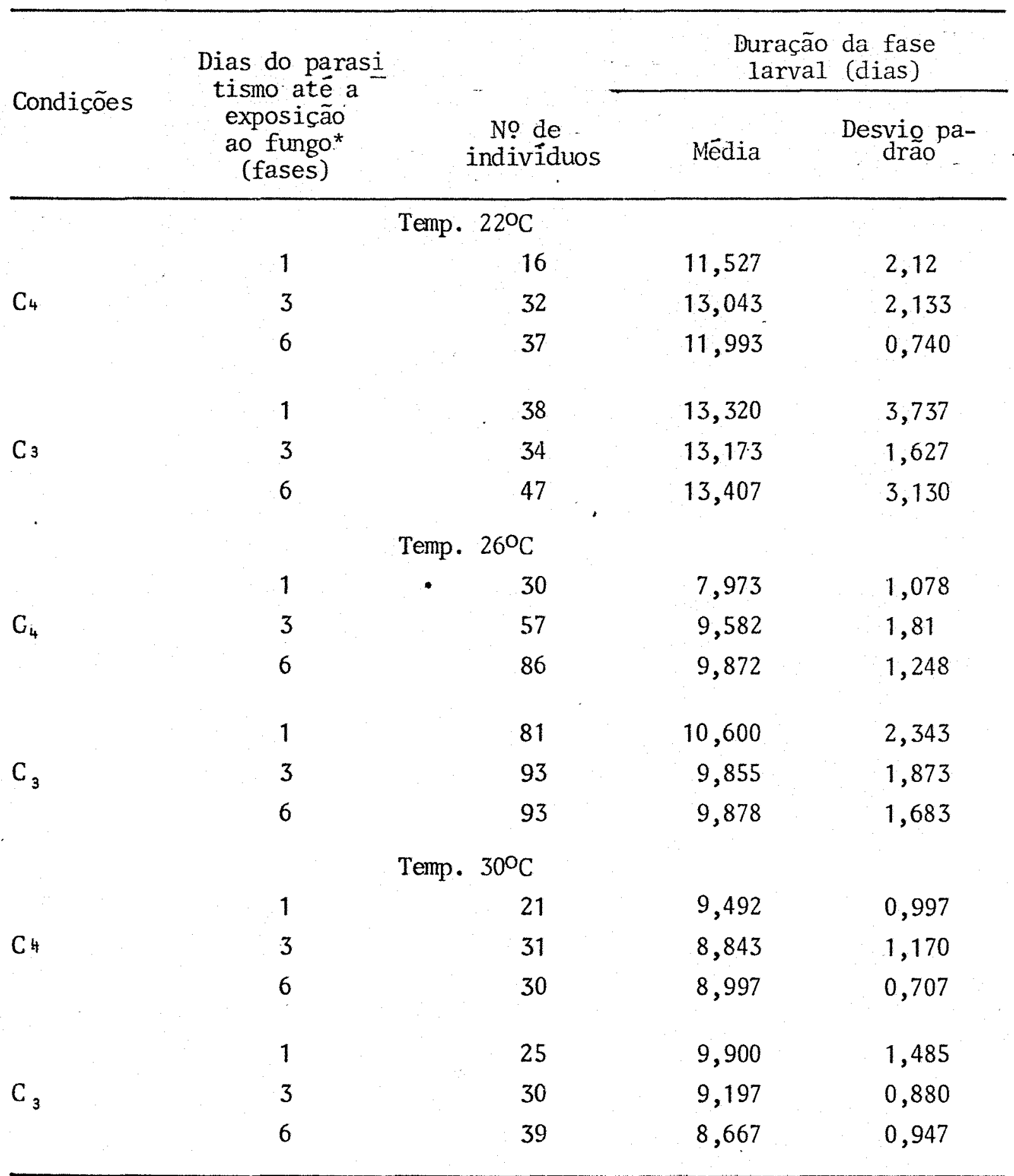

* $1 \times 10^{7}$ conídios $/ \mathrm{ml}$ 
Tabela 7 - Resultados da anālise estatística para a duração da fase larva1 de A. flavipes em lagartas de $D$. saccharalis infectadas e não infectadas por $M$. anisopliae em diferentes temperaturas.

\begin{tabular}{lccc}
\hline & \multicolumn{3}{c}{ Temperatura $\left({ }^{\circ} \mathrm{C}\right)$} \\
\cline { 2 - 4 } & 22 & 26 & 30 \\
\hline Teste F p/condições & $1,81 \mathrm{NS}$ & $2,51 \mathrm{NS}$ & $0,15 \mathrm{NS}$ \\
Teste F p/fases & $0,23 \mathrm{NS}$ & $0,33 \mathrm{NS}$ & $1,99 \mathrm{NS}$ \\
Teste F p/interações & $0,37 \mathrm{NS}$ & $1,86 \mathrm{NS}$ & $0,41 \mathrm{NS}$ \\
C.V. & $13,764200^{\circ}$ & $1,9,042500^{\circ}$ & $8,598080^{\circ}$ \\
Q.M. Res. & 3,0768300 & 3,3604700 & 0,6233390 \\
Médias das Condições & & & \\
\hline Condição 4 (M.a.+A.f.) & 12,18780 & 9,14222 & 9,11056 \\
Condição 3 (A.f.) & 13,30000 & 10,11110 & 9,25444 \\
Mëdias de Fases & & & 9,83167 \\
\hline Fase 1 (1 dia após) & 12,42330 & 9,28667 & 9,69583 \\
Fase 2 (3 dias apös) & 13,10830 & 9,71833 & 9,02000 \\
Fase 3 (4 dias apös) & 12,70000 & 9,87500 & 8 \\
\hline
\end{tabular}

M.a. = Metarhizium anisopliae

A.f. = Apanteles flavipes 
Tabela 8 - Duração mëdia da fase larval de Metagonistylum minense em lagar tas de $D$. saccharalis infectadas e não infectadas por $M$. anisopliae nas temperaturas de 22,26 e $30^{\circ} \mathrm{C}$.

\begin{tabular}{|c|c|c|c|c|}
\hline \multirow{2}{*}{ Condições } & \multirow{2}{*}{$\begin{array}{l}\text { Dias do parasi } \\
\text { tismo até a } \\
\text { exposição } \\
\text { ao fungo* } \\
\text { (fases) }\end{array}$} & \multirow[b]{2}{*}{$\begin{array}{l}\text { No de in- } \\
\text { divíduos }\end{array}$} & \multicolumn{2}{|c|}{$\begin{array}{c}\text { Duração da fase larval } \\
\text { (dias) }\end{array}$} \\
\hline & & & Média & $\begin{array}{l}\text { Desvio pa- } \\
\text { drão }\end{array}$ \\
\hline & & Temp. $22^{\circ} \mathrm{C}$ & & \\
\hline & 1 & 36 & 7,457 & 1,267 \\
\hline \multirow[t]{3}{*}{$\mathrm{C}_{6}$} & 3 & 38 & 7,235 & 1,023 \\
\hline & 6 & 45 & 7,567 & 1,073 \\
\hline & 1 & 38 & 7,803 & 0,973 \\
\hline \multirow{2}{*}{$\begin{array}{c}\mathrm{C}_{5} \\
.\end{array}$} & 3 & 37 & 7,517 & 0,733 \\
\hline & 6 & 44 & 7,353 & 1,377 \\
\hline & & Temp. $26^{\circ} \mathrm{C}$ & & \\
\hline * & 1 & 49 & 6,743 & 0,788 \\
\hline \multirow[t]{3}{*}{$\mathrm{C}_{6}$} & 3 & 70 & 6,672 & 0,588 \\
\hline & 6 & 67 & 7,110 & 0,708 \\
\hline & 1 & 67 & 7,265 & 1,890 \\
\hline \multirow[t]{4}{*}{$\mathrm{C}_{5}$} & 3 & 64 & 6,890 & 0,752 \\
\hline & 6 & 64 & 7,088 & 0,908 \\
\hline & & Temp. $30^{\circ} \mathrm{C}$ & . & \\
\hline & 1 & 25 & 6,627 & 1,237 \\
\hline \multirow[t]{3}{*}{$\mathrm{C}_{6}$} & 3 & 34 & 6,890 & 1,027 \\
\hline & 6 & 25 & 7,032 & 1,013 \\
\hline & 1 & 28 & 6,770 & 0,957 \\
\hline \multirow[t]{2}{*}{$\mathrm{C}_{5}$} & 3 & 41 & 6,927 & 1,649 \\
\hline & 6 & 35 & 7,029 & 0,664 \\
\hline
\end{tabular}

* $1 \times 10^{7}$ conídios $/ \mathrm{ml}$ 
Tabela 9 - Resultados da análise estatística para a duração da fase larval de Metagonistylum minense em lagartas de $D$. saccharalis, infectadas e não infectadas por M. anisopliae em diferentes temperaturas.

\begin{tabular}{lccc}
\hline & \multicolumn{3}{c}{ Temperatutras $\left({ }^{\circ} \mathrm{C}\right)$} \\
\cline { 2 - 4 } & 22 & 26 & 30 \\
\hline Teste F p/condições & $0,13 \mathrm{NS}$ & $1,72 \mathrm{NS}$ & $0,06 \mathrm{NS}$ \\
Teste F p/fases & $0,16 \mathrm{NS}$ & $1,06 \mathrm{NS}$ & $0,74 \mathrm{NS}$ \\
Teste F p/interações & $0,23 \mathrm{NS}$ & $0,74 \mathrm{NS}$ & $0,04 \mathrm{NS}$ \\
C.V. & $10,669900^{\circ}$ & $7,878240^{\circ}$ & $6,984370^{\circ}$ \\
Q.M. Res. & 0,6387260 & 0,3007810 & 0,2307920
\end{tabular}

Médias das Condições

\begin{tabular}{llll}
\hline Condição 6 (M.m.+M.a.) & 7,42278 & 6,84167 & 6,85000 \\
Condição 5 (M.m.) & 7,55778 & 7,08111 & 6,90667
\end{tabular}

Médias das Fases

Fase 1 (1 dia apös)

Fase 2 ( 3 dias após)

Fase 3 (6 dias após)
7,63000

7,00417

6,69833

7,37583

6,78083

6,90500

7,46500

7,03167

M. m. = Metagonistylum minense

M. a. =Metarhizium anisopliae 
Tabela 10 - Duração média da fase larval de $P$. claripalpis em lagartas de D. saccharalis infectadas e não infectadas por $M$. anisopliae nas temperaturas de 22,26 e $30^{\circ} \mathrm{C}$.

\begin{tabular}{|c|c|c|c|c|}
\hline \multirow{2}{*}{ Condições } & \multirow{2}{*}{$\begin{array}{l}\text { Dias do parasi } \\
\text { tismo ate a } \\
\text { exposição } \\
\text { ao fungo* } \\
\text { (fases) }\end{array}$} & \multirow[b]{2}{*}{$\begin{array}{l}\text { No de } \\
\text { indiv. }\end{array}$} & \multicolumn{2}{|c|}{$\begin{array}{c}\text { Duração da fase larva1 } \\
\text { (dias) }\end{array}$} \\
\hline & & & Média & $\begin{array}{l}\text { Desvio } \\
\text { padrão }\end{array}$ \\
\hline
\end{tabular}

Temp. $22^{\circ} \mathrm{C}$

$\begin{array}{ccccc} & 1 & 50 & 8,257 & 1,977 \\ \mathrm{C}_{8} & 51 & 7,453 & 0,890 \\ & 3 & 49 & 8,717 & 1,807 \\ & 6 & 51 & 8,413 & 2,200 \\ \mathrm{C}_{7} & 1 & 50 & 7,663 & 0,887 \\ & 3 & 44 & 8,237 & 1,447\end{array}$

Temp. $26^{\circ} \mathrm{C}$

$\begin{array}{ccccc} & 1 & 65 & 6,813 & 1,390 \\ \mathrm{C}_{8} & 3 & 88 & 6,640 & 0,950 \\ & 6 & 97 & 7,272 & 1,163 \\ & 1 & 99 & 7,113 & 2,080 \\ \mathrm{C}_{7} & 3 & 95 & 7,002 & 0,973 \\ & 1 & 98 & 7,698 & 1,280\end{array}$

Temp. $30^{\circ} \mathrm{C}$

$\begin{array}{ccccc} & 1 & 30 & 6,533 & 1,843 \\ \mathrm{C}_{8} & 3 & 32 & 6,600 & 1,347 \\ & 6 & 49 & 6,557 & 0,703 \\ & 1 & 33 & 6,953 & 1,287 \\ \mathrm{C}_{7} & 3 & 38 & 6,727 & 1,943 \\ & 6 & 44 & 6,583 & 0,627\end{array}$

* $1 \times 10^{7}$ conidios $/ \mathrm{ml}$ 
Tabela 11 - Resultados da análise estatística para a duração da fase larval de $P$. Claripalpis em lagartas de $D$. saccharalis infectadas e não infectadas por M. anisopliae em diferentes temperaturas.

Temperaturas $\left({ }^{\circ} \mathrm{C}\right)$

$22 \quad 26 \quad 30$

Teste $\mathrm{F} \mathrm{p} /$ condições

$0,01 \mathrm{NS}$

2,62 NS

$0,33 \mathrm{NS}$

Teste $\mathrm{F} \mathrm{p}$ /fases

$2,26 \mathrm{NS}$

3,24 NS

$0,09 \mathrm{NS}$

Teste $\mathrm{F}$ p/interações

$0,34 \mathrm{NS}$

$0,03 \mathrm{NS}$

0,13 NS

C.V.

$9,925090^{\circ}$

9,486580

$10,565100 \%$

Q.M. Res.

0,6500360

0,4523530

0,4949400

Médias das Condições

$\begin{array}{llll}\text { Condição } 8 \text { (P.c.+M.a.) } & 8,14222 & 6,90833 & 6,56333 \\ \text { Condição } 7 \text { (P.c.) } & 8,10445 & 7,27111 & 6,75445\end{array}$

Médias das Fases

Fase 1 (1 dia após)

8,33500

6,96333

6,74333

Fase 2 ( 3 dias apōs)

7,55833

6,82083

6,66333

Fase 3 (6 dias após)

8,47667

7,48500

6,57000

P.c. =Paratheresia claripalpis

M. a. Metarhizium anisopliae 
Esses dados discordam dos encontrados por LAIGO e TAMASHIRO (1967) e BROOKS e CRANFORD (1972) para outras espé cies de patögenos e de parasitos.

O parasito A. Glavipes novamente pode ser consi derado um pouco mais sensivel, jā que, nas fases em que ocorre maior competição ( 1 e 2 ), verifica-se uma pequena diminuição no seu período de desenvolvimento.

Com relação às diferentes temperaturas deve - se salientar que as análises estatísticas foram fejtas separadamente, como se cada temperatura correspondesse a um experimento distinto. Dessa maneira, o alongamento dos estágios de desenvolvimento dos parasitos nas temperaturas mais baixas não foi detectado pela anālise estatística.

Nas Tabelas 12 a 17 referentes à duração média do estágio pupal dós parasitos e aos resultados da análise estatística, verifica-se um comportamento semelhante para os três parasitos, isto é, observa-se uma variação maior dos dados nos tratamentos em que a interação está presente.

No que se refere ao A. blavipes, essa variação não foi acusada pela análise estatística, o que se explica pela ocorrência de um maior coeficiente de variação.

Atravēs das médias dos tratamentos verificou-se que de modo geral, ocorreu um pequeno encurtamento no período pupal dos insetos pertencentes aos tratamentos onde o fungo e $\underline{s}$ tava presente, concordando com o relatado por LAIGO e PASCHKE (1968). Porém, de acordo com HAMM et alii (1983), isso não po 
Tabela 12 - Duração média da fase pupal de A. flavípes em desenvolvimen to sobre lagartas de $D$. saccharalis, infectadas e não infecta das por M. anisopliae nas temperaturas de 22,26 e $30^{\circ} \mathrm{C}$.

\begin{tabular}{|c|c|c|c|c|}
\hline \multirow{2}{*}{ Condições } & \multirow{2}{*}{$\begin{array}{c}\text { Dias do parasi } \\
\text { tismo atê a } \\
\text { exposição } \\
\text { ao fungo* } \\
\text { (fases) }\end{array}$} & \multicolumn{3}{|c|}{ Duração da fase pupal (em dias) } \\
\hline & & $\begin{array}{c}\text { No de mas- } \\
\text { sas } \\
\text { viâveis }\end{array}$ & Média & $\begin{array}{l}\text { Desvio } \\
\text { padrão }\end{array}$ \\
\hline & & Temp. $22^{\circ} \mathrm{C}$ & & \\
\hline & 1 & 15 & 8,477 & 1,493 \\
\hline \multirow{3}{*}{$\mathrm{C}_{4}$} & 3 & 31 & 7,820 & 0,843 \\
\hline & 6 & 35 & 6,767 & 0,793 \\
\hline & 1 & 31 & 7,750 & 1,138 \\
\hline \multirow[t]{4}{*}{$\mathrm{C}_{3}$} & 3 & 30 & 7,650 & 0,847 \\
\hline & 6 & 45 & 7,383 & 1,317 \\
\hline & & Temp. $26^{\circ} \mathrm{C}$ & & \\
\hline & 1 & 23 & 4,767 & 0,400 \\
\hline \multirow[t]{3}{*}{$\mathrm{C}_{4}$} & 3 & 51 & 5,677 & 0,720 \\
\hline & 6 & 77 & 5,253 & 0,860 \\
\hline & 1 & 77 & 5,257 & 0,713 \\
\hline \multirow[t]{4}{*}{$\mathrm{C}_{3}$} & 3 & 86 & 5,503 & 0,717 \\
\hline & 6 & 92 & 5,662 & 0,756 \\
\hline & & Terp. $30^{\circ} \mathrm{C}$ & & \\
\hline & 1 & 16 & 5,100 & 0,980 \\
\hline \multirow[t]{2}{*}{$\mathrm{C}_{4}$} & 3 & 27 & 4,477 & 0,550 \\
\hline & 6 & 19 & 5,158 & 0,877 \\
\hline $\mathrm{C}$ & 1 & 22 & 5,136 & 0,873 \\
\hline \multirow[t]{2}{*}{3} & 3 & 23 & 4,777 & 0,570 \\
\hline & 6 & 32 & 4,863 & 0,713 \\
\hline
\end{tabular}


Tabela 13 - Resultados da anälise estatística para duração média : da fase pupal do parasito A. flavipes em desenvolvimento sobre lagartas de $D$. saccharalis infectadas e não infectadas por $M$. a nisopliae en diferentes temperaturas.

\begin{tabular}{lccc}
\hline & \multicolumn{3}{c}{ Temperaturas ( $\left.{ }^{\circ} \mathrm{C}\right)$} \\
\cline { 2 - 4 } & $0,06 \mathrm{NS}$ & $0,58 \mathrm{NS}$ & $0,00 \mathrm{NS}$ \\
\hline Teste F p/condições & $2,64 \mathrm{NS}$ & $1,21 \mathrm{NS}$ & $1,07 \mathrm{NS}$ \\
Teste F p/fases & $1,09 \mathrm{NS}$ & $0,43 \mathrm{NS}$ & $0,35 \mathrm{NS}$ \\
Teste F p/interações & $10,372900^{\circ}$ & $17,793100^{\circ}$ & $12,496600^{\circ}$ \\
C.V. & 0,628222 & 0,907207 & 0,377932 \\
Q.M. Res. & & & \\
\hline
\end{tabular}

Mëdias das Condições

\begin{tabular}{llll}
\hline Condição 4 (A.f.+M.a.) & 7,68778 & 5,23222 & 4,91222 \\
Condição 3 (A.f.) & 7,59445 & 5,47389 & 4,92667
\end{tabular}

Mëdias das Fases

Fase 1 (1 dia após)

Fase 2 ( 3 dias após)

Fase 3 (6 dias após)

A.f.=Apanteles flavipes

M.a.=Metarhizium anisopliae

$8,11333 \quad 5,01167 \quad 5,12000$

$\begin{array}{lll}7,73500 & 5,59000 & 4,62667\end{array}$

$7,07500 \quad 5,45750 \quad 5,01167$ 
Tabela 14 - Duração média da fase pupal de Metagonistylum minense em de senvolvimento sobre lagartas de $D$. saccharalis, infectadas $e$ não infectadas por Metarhizium anisopliae nas temperaturas de 22,26 e $30^{\circ} \mathrm{C}$.

\begin{tabular}{|c|c|c|c|c|}
\hline \multirow[b]{2}{*}{ Condi ções } & \multirow[b]{2}{*}{$\begin{array}{l}\text { Dias do parasi } \\
\text { tismo até a } \\
\text { exposição } \\
\text { ao fungo* } \\
\text { (fases) }\end{array}$} & \multicolumn{3}{|c|}{ Duração da fase pupal (em dias) } \\
\hline & & $\begin{array}{l}\text { No de } \\
\text { pupas } \\
\text { viaveis }\end{array}$ & Média & $\begin{array}{l}\text { Desvio } \\
\text { padrão }\end{array}$ \\
\hline \multicolumn{5}{|c|}{ Temp. $22^{\circ} \mathrm{C}$} \\
\hline & 1 & 28 & 12,003 & 1,017 \\
\hline \multirow[t]{3}{*}{$\mathrm{C}_{6}$} & 3 & 32 & 9,627 & 1,560 \\
\hline & 6 & 40 & 11,020 & 1,187 \\
\hline & 1 & 33 & 10,677 & 1,317 \\
\hline \multirow[t]{4}{*}{$\mathrm{C}_{5}$} & 3 & 36 & 11,042 & 0,973 \\
\hline & 6 & 33 & 11,193 & 0,403 \\
\hline & & $\operatorname{mp} \cdot 26^{\circ} \mathrm{C}$ & & \\
\hline & 1 & 37 & 8,730 & 0,618 \\
\hline \multirow[t]{3}{*}{$\mathrm{C}_{6}$} & 3 & 59 & 9,328 & 0,562 \\
\hline & 6 & 53 & 9,050 & 0,697 \\
\hline & 1 & 60 & 8,753 & 0,650 \\
\hline \multirow[t]{4}{*}{$\mathrm{C}_{5}$} & 3 & 56 & 9,268 & 0,427 \\
\hline & 6 & 55 & 9,323 & 0,680 \\
\hline & & emp. $30^{\circ} \mathrm{C}$ & & \\
\hline & 1 & 12 & 7,917 & 0,320 \\
\hline \multirow[t]{3}{*}{$\mathrm{C}_{6}$} & 3 & 11 & 7,167 & 0,520 \\
\hline & 6 & 15 & 7,037 & 0,770 \\
\hline & 1 & 18 & 7,453 & 0,733 \\
\hline \multirow[t]{2}{*}{$C_{5}$} & 3 & 19 & 7,660 & 0,760 \\
\hline & 6 & 17 & 7,397 & 1,127 \\
\hline
\end{tabular}


Tabela 15 - Resultados da anälise estatística para duração mëdia da fase pupal do parasito Metagonistylum minense em desenvolvimento sobre lagartas de $D$. saccharalis infectadas e não infectadas por Metarhizium anisopliae e em diferentes temperaturas.

\begin{tabular}{lccc}
\hline & \multicolumn{3}{c}{ Temperaturas (OC) } \\
\cline { 2 - 4 } & \multicolumn{1}{c}{22} & 26 & 30 \\
\hline Teste F p/condições & $0,02 \mathrm{NS}$ & $0,43 \mathrm{NS}$ & $0,61 \mathrm{NS}$ \\
Teste F p/fases & $0,87 \mathrm{NS}$ & $6,93^{* *}$ & $2,65 \mathrm{NS}$ \\
Teste F p/interação & $1,48 \mathrm{NS}$ & $0,56 \mathrm{NS}$ & $3,21 \mathrm{NS}$ \\
C.V. & $12,663400^{\circ}$ & $4,383820^{\circ}$ & $4,760890^{\circ}$ \\
Q.M. Res. & 1,9152800 & 0,1580860 & 0,1254080
\end{tabular}

Médias das Condições

\begin{tabular}{lccc}
\hline Condição 6 (M.m.+M.a.) & 10,88670 & 9,02611 & 7,37333 \\
Condição 5 (M.m.) & 10,97060 & 9,11333 & 7,50333 \\
& & & \\
Mëdias das Fases & & & \\
\hline Fase 1 (1 dia após) & 11,34000 & $8,72667 \mathrm{~B}$ & 7,68500 \\
Fase 2 (3 dias após) & 10,33420 & $9,29583 \mathrm{~A}$ & 7,41333 \\
Fase 3 (6 dias apös) & 11,11170 & $9,18667 \mathrm{~A}$ & 7,21667 \\
$\Delta(5 \%)$ & - & 0,404398 & - \\
\hline
\end{tabular}

M.m. = Metagonistylum minense

M.a.= Metarhizium anisopliae 
Tabela 16 - Duração média da fase pupal de $P$. claripalpis em desenvolvi mento sobre lagartas de $D$. saccharalis, infectadas e não infec. tadas por M. anisopliae nas temperaturas de 22,26 e $30^{\circ} \mathrm{C}$.

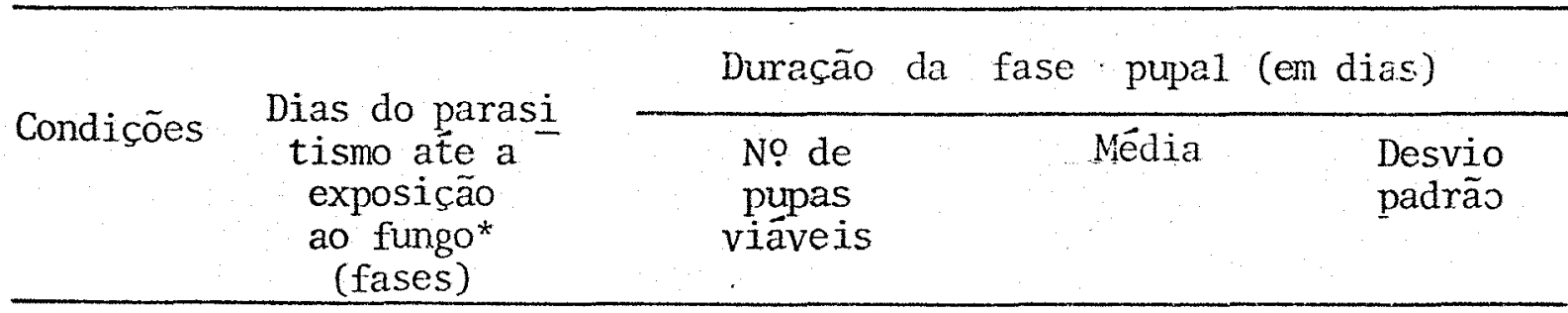

Temp. $22^{\circ} \mathrm{C}$

$\begin{array}{ccccc} & 1 & 34 & 23,600 & 1,323 \\ \mathrm{C}_{8} & 33 & 23,903 & 1,383 \\ & 6 & 30 & 23,040 & 1,330 \\ & 1 & 35 & 21,527 & 1,560 \\ \mathrm{C}_{7} & 3 & 38 & 21,363 & 0,783 \\ & 6 & 37 & 23,487 & 1,453\end{array}$

Temp. $26^{\circ} \mathrm{C}$

$\begin{array}{ccccc} & 1 & 50 & 16,903 & 1,065 \\ \mathrm{C}_{8} & 3 & 64 & 17,365 & 0,918 \\ & 6 & 67 & 18,208 & 1,360 \\ & 1 & 74 & 17,270 & 1,033 \\ \mathrm{C}_{7} & 3 & 74 & 18,406 & 1,150 \\ & 6 & 76 & 17,870 & 0,745\end{array}$

Temp. $30^{\circ} \mathrm{C}$

$\begin{array}{ccccc} & 1 & 21 & 14,173 & 1,347 \\ \mathrm{C}_{8} & 3 & 21 & 14,952 & 1,040 \\ & 6 & 27 & 15,583 & 1,040 \\ & 1 & 22 & 14,370 & 1,760 \\ \mathrm{C}_{7} & 3 & 23 & 14,480 & 1,180 \\ & 6 & 23 & 14,700 & 0,550\end{array}$


Tabela 17 - Resultados da anälise estatística para duração mẻdia da fase pupal do parasito $P$. Claripalpis em desenvolvimento sobre lagartas de $D$. saccharalis, infectadas e não infectadas por $M$. anisopliae em diferentes temperaturas.

\begin{tabular}{|c|c|c|c|}
\hline & \multicolumn{3}{|c|}{ Temperaturas $\left({ }^{\circ} \mathrm{C}\right)$} \\
\hline & 22 & 26 & 30 \\
\hline Teste F p/condições & $2,15 \mathrm{NS}$ & $2,90 \mathrm{NS}$ & $0,83 \mathrm{NS}$ \\
\hline Teste F p/fases & $0,22 \mathrm{NS}$ & $6,63^{* *}$ & $1,41 \mathrm{NS}$ \\
\hline Teste $\mathrm{F}$ p/interações & $0,95 \mathrm{NS}$ & 3,27 NS & $0,55 \mathrm{NS}$ \\
\hline C.V. & $8,810660 \%$ & $3,754430 \%$ & $6,116290 \%$ \\
\hline Q.M. Res. & 4,0422900 & 0,4406640 & 0,8094720 \\
\hline
\end{tabular}

Médias das Condições

$\begin{array}{llll}\text { Condição } 8 \text { (P.c.+M.a.) } & 23,51450 & 17,49220 & 14,90330 \\ \text { Condição } 7 \text { (P.c.) } & 22,12440 & 17,87000 & 14,51670\end{array}$

Mëdias de Fases

Fase 1 (1 dia apōs)

Fase 2 ( 3 dias apös)

Fase 3 (6 dias após)

$\Delta(5 \%)$
22,56330

22,63330

23,26170

$-$
$17,11830 \mathrm{~B}$

14,27170

$17,88580 \mathrm{~A} \quad 14,71670$

18,03920 A $\quad 15,14170$

0,675176

P.c.=Paratheresia claripalpis

M.a.= Metarhizium anisopliae 
de ser considerado ecologicamente importante.

Ainda, com relação a esse parâmetro, BROOKS e CRANFORD (1972), estudando a interferência de um protozoário so bre um braconideo que se desenvolviam em lagartas de Heliothis, observaram que apesar de não ter ocorrido efeito substancial sobre o período de desenvolvimento do parasito, houve uma dimi nuição na porcentagem de emergência de pré-pupas do bracon deo.

o último parâmetro estudado, representado pela porcentagem de emergência de adultos dos parasitos em lagartas infectadas e não infectadas, está relacionado nas Tabelas 18 a 23. Nas Tabelas 19,21 e 23 referentes aos resultados da análí se estatistica, os dados foram transformados para arco seno $(\mathrm{SQR} \%)$.

Verifica-se pela Tabela 19 referente ao A. blavipes, que houve diferença estatistica entre o tratamento onde ocorreu interação e o tratamento onde o parasito atuou isolada mente na temperatura de $26^{\circ} \mathrm{C}$. No entanto, a diminuição da porcentagem de emergência não revelou uma tendência, jâ que nas outras duas temperaturas estudadas, houve uma inversão de resultados. Também, pode-se verificar que os dados são muito variāveis sendo difícil de se concluir a respeito dessa anälise. 
Tabela 18 - Porcentagem média de emergência de adultos de A. flavipes com desenvolvimento em lagartas de $D$. saccharalis, infectadas e não infectadas por $M$. anisopliae nas temperaturas de 22,26 e $30^{\circ} \mathrm{C}$ (dados transformados em arco seno).

\begin{tabular}{|c|c|c|c|c|}
\hline \multirow[b]{2}{*}{ Condições } & \multirow{2}{*}{$\begin{array}{l}\text { Dias do parasi } \\
\text { tismo até a } \\
\text { exposição } \\
\text { ao fungo* } \\
\text { (fases) }\end{array}$} & \multicolumn{3}{|c|}{ \% de emergência de adultos } \\
\hline & & $\begin{array}{l}\text { No total } \\
\text { de massas }\end{array}$ & média & $\begin{array}{l}\text { Desvio } \\
\text { padrão } \\
\text { médio }\end{array}$ \\
\hline
\end{tabular}

Temp. $22^{\circ} \mathrm{C}$

$\begin{array}{rrrrr} & 1 & 16 & 94,44 & 9,62 \\ \mathrm{C}_{4} & 32 & 97,62 & 4,12 \\ & 3 & 37 & 95,00 & 4,41 \\ & 6 & 38 & 79,74 & 17,55 \\ \mathrm{C}_{3} & 1 & 33 & 90,86 & 0,83 \\ & 3 & 47 & 95,24 & 8,25\end{array}$

Temp. $26^{\circ} \mathrm{C}$

\begin{tabular}{|c|c|c|c|c|}
\hline & 1 & 30 & 78,05 & 18,49 \\
\hline \multirow[t]{2}{*}{$C_{4}$} & 3 & 56 & 91,81 & 10,16 \\
\hline & 6 & 84 & 90,84 & 8,83 \\
\hline & 1 & 81 & 95,21 & 7,92 \\
\hline$C_{3}$ & 3 & 91 & 95,14 & 7,64 \\
\hline & 6 & 94 & 97,21 & 4,83 \\
\hline
\end{tabular}

Temp. $30^{\circ} \mathrm{C}$

$\begin{array}{rrrrr} & 1 & 19 & 81,11 & 20,09 \\ \mathrm{C}_{4} & 3 & 30 & 87,50 & 21,65 \\ & 6 & 28 & 70,00 & 12,02 \\ & 1 & 25 & 86,67 & 5,77 \\ \mathrm{C}_{3} & 3 & 29 & 78,04 & 11,12 \\ & 6 & 37 & 86,35 & 0,55\end{array}$

* $1 \times 10^{7}$ conídios $/ \mathrm{ml}$ 
Tabela 19 - Resultados da análise estatística para porcentagem média de emergência de adultos de A. flavipes com desenvolvimento em lagartas de $D$. saccharalis, infectadas e não infectadas por $M . \underline{a}$ nisopliae em diferentes temperaturas.

\begin{tabular}{lccc}
\hline & \multicolumn{3}{c}{ Temperaturas $\left.{ }^{\circ} \mathrm{C}\right)$} \\
\cline { 2 - 4 } & $1,63 \mathrm{NS}$ & $8,95^{* *}$ & $0,04 \mathrm{NS}$ \\
\hline Teste F p/condições & $0,34 \mathrm{NS}$ & $2,92 \mathrm{NS}$ & $0,47 \mathrm{NS}$ \\
Teste F p/fases & $0,81 \mathrm{NS}$ & $2,58 \mathrm{NS}$ & $1,30 \mathrm{NS}$ \\
Teste F p/interação & $16,683200^{\circ}$ & $18,050700^{\circ}$ & $20,850500^{\circ}$ \\
C.V. & 170,00900 & 189,97300 & 196,30300 \\
Q.M. Res. & & &
\end{tabular}

Mëdias das Condições

$\begin{array}{llll}\text { Condição } 4 \text { (A.f.+M.a.) } & 82,07360 & 69,48670 \mathrm{~B} & 67,81320 \\ \text { Condição } 3 \text { (A.f.) } & 74,23670 & 83,22880 \mathrm{~A} & 66,57970\end{array}$

Médias de Fases

Fase 1 (1 dia apōs)

74,83350

68,50640

68,87270

Fase 2 ( 3 dias apôs)

78,62410

80,41310

69,98840

Fase 3 (6 dias após)

81,00780

80,15380

62,72830
A.f. =Apanteles flavipes
M.a. = Metarhizium anisopliae 
Tabela 20 - Porcentagem média de emergência de adultos de Metagonistulum minense en desenvolvimento sobre lagartas de $D$. saccharalis, in fectadas e não infectadas por $M$. anisopliae nas temperaturas de 22,26 e $30^{\circ} \mathrm{C}$.

\begin{tabular}{|c|c|c|c|c|}
\hline \multirow{2}{*}{ Condições } & \multirow{2}{*}{$\begin{array}{c}\text { Dias do parasi } \\
\text { tismo atê a } \\
\text { exposição } \\
\text { ao fungo* } \\
\text { (fases) }\end{array}$} & \multicolumn{3}{|c|}{$\%$ de emergência de adultos } \\
\hline & & $\begin{array}{l}\text { No total } \\
\text { de pupas }\end{array}$ & média & $\begin{array}{l}\text { Desvio } \\
\text { padrão } \\
\text { médio }\end{array}$ \\
\hline \multicolumn{5}{|c|}{ Temp. $22^{\circ} \mathrm{C}$} \\
\hline & 1 & 34 & 85,56 & 13,47 \\
\hline \multirow[t]{3}{*}{$\mathrm{C}_{6}$} & 3 & 38 & 84,23 & 11,51 \\
\hline & 6 & 44 & 90,29 & 10,85 \\
\hline & 1 & 38 & 85,08 & 8,31 \\
\hline \multirow[t]{2}{*}{$\mathrm{C}_{5}$} & 3 & 37 & 96,67 & 5,77 \\
\hline & 6 & 43 & 76,31 & 21,41 \\
\hline \multicolumn{5}{|c|}{ Temp. $26^{\circ} \mathrm{C}$} \\
\hline & 1 & 49 & 73,11 & 17,20 \\
\hline \multirow[t]{3}{*}{$\mathrm{C}_{6}$} & 3 & 70 & 83,98 & 13,28 \\
\hline & 6 & 67 & 80,54 & 13,96 \\
\hline & 1 & 67 & 89,73 & 9,30 \\
\hline \multirow[t]{4}{*}{$\mathrm{C}_{5}$} & 3 & 64 & 89,80 & 10,64 \\
\hline & 6 & 64 & 85,21 & 5,69 \\
\hline & & Temp. $30^{\circ} \mathrm{C}$ & & \\
\hline & 1 & 24 & 55,00 & 18,03 \\
\hline \multirow[t]{3}{*}{$\mathrm{C}_{6}$} & 3 & 34 & 30,78 & 10,76 \\
\hline & 6 & 25 & 60,18 & 25,32 \\
\hline & 1 & 28 & 65,32 & 9,36 \\
\hline \multirow[t]{2}{*}{$C_{5}$} & 3 & 41 & 46,15 & 9,77 \\
\hline & 6 & 35 & 49,22 & 12,51 \\
\hline
\end{tabular}

* $1 \times 10^{7}$ conídios $/ \mathrm{ml}$ 
Tabela 21 - Resultados da anālise estatística para porcentagem de emergência de adultos de Metagonistylum minense com desenvolvimento em lagartas de $v$. saccharalis infectadas e não infectadas por Metarhizium anisopliae em diferentes temperaturas.

Temperaturas $\left({ }^{\circ} \mathrm{C}\right)$

$22 \quad 30$

Teste $\mathrm{F}$ p/condições

$\begin{array}{lll}0,03 \mathrm{NS} & 4,13 \mathrm{NS} & 0,36 \mathrm{NS} \\ 0,37 \mathrm{NS} & 0,77 \mathrm{NS} & 3,09 \mathrm{NS} \\ 1,68 \mathrm{NS} & 1,07 \mathrm{NS} & 1,27 \mathrm{NS}\end{array}$

C.V.

$17.959300^{\circ} \quad 14,775500 \%$

$20,631200 \%$

Q.M. Res.

$167,17900 \quad 104,17400$

89,22460

Mëdias das Condições

\begin{tabular}{llll}
\hline Condição 6 (M.m.+M.a.) & 71,51570 & 65,62180 & 44,44220 \\
Condição 5 (M.m.) & 72,47380 & 72,53350 & 47,12680
\end{tabular}

Médias das Fases

Fase 1 (1 dia apōs)

69,75920

68,11340

51,05340

Fase 2 ( 3 dias apōs)

75,67870

72,01070

38,13790

Fase 3 (6 dias apōs)

70,54640

67,10940

48,16220

M.m. = Metagonistylum minense

M.a.=Metarhizium anisopliae 
Tabela 22 - Porcentagem média de emergência de adultos de $P$. claripalpis em desenvolvimento sobre lagartas de $D$. saccharalis, infectadas e não infectadas por $M$. anisopliae nas temperaturas de 22 , 26 e $30^{\circ} \mathrm{C}$.

\begin{tabular}{|c|c|c|c|c|}
\hline \multirow[b]{2}{*}{ Condições } & \multirow[b]{2}{*}{$\begin{array}{l}\text { Dias do parasi } \\
\text { tismo ate a } \\
\text { exposição } \\
\text { ao fungo* } \\
\text { (fases) }\end{array}$} & \multicolumn{3}{|c|}{$\frac{o}{b}$ de emergência de adultos } \\
\hline & & $\begin{array}{l}\text { No total } \\
\text { de pupas }\end{array}$ & mêdia & $\begin{array}{l}\text { Desvio } \\
\text { padrão }\end{array}$ \\
\hline
\end{tabular}

Temp. $22^{\circ} \mathrm{C}$

$\begin{array}{rrrrr} & 1 & 45 & 75,37 & 6,81 \\ \mathrm{C}_{8} & 50 & 65,58 & 23,87 \\ & 3 & 44 & 68,38 & 15,46 \\ & 6 & 47 & 74,66 & 3,53 \\ \mathrm{C}_{7} & 1 & 48 & 79,32 & 5,67 \\ & 3 & 44 & 85,18 & 16,97\end{array}$

Temp. $26^{\circ} \mathrm{C}$

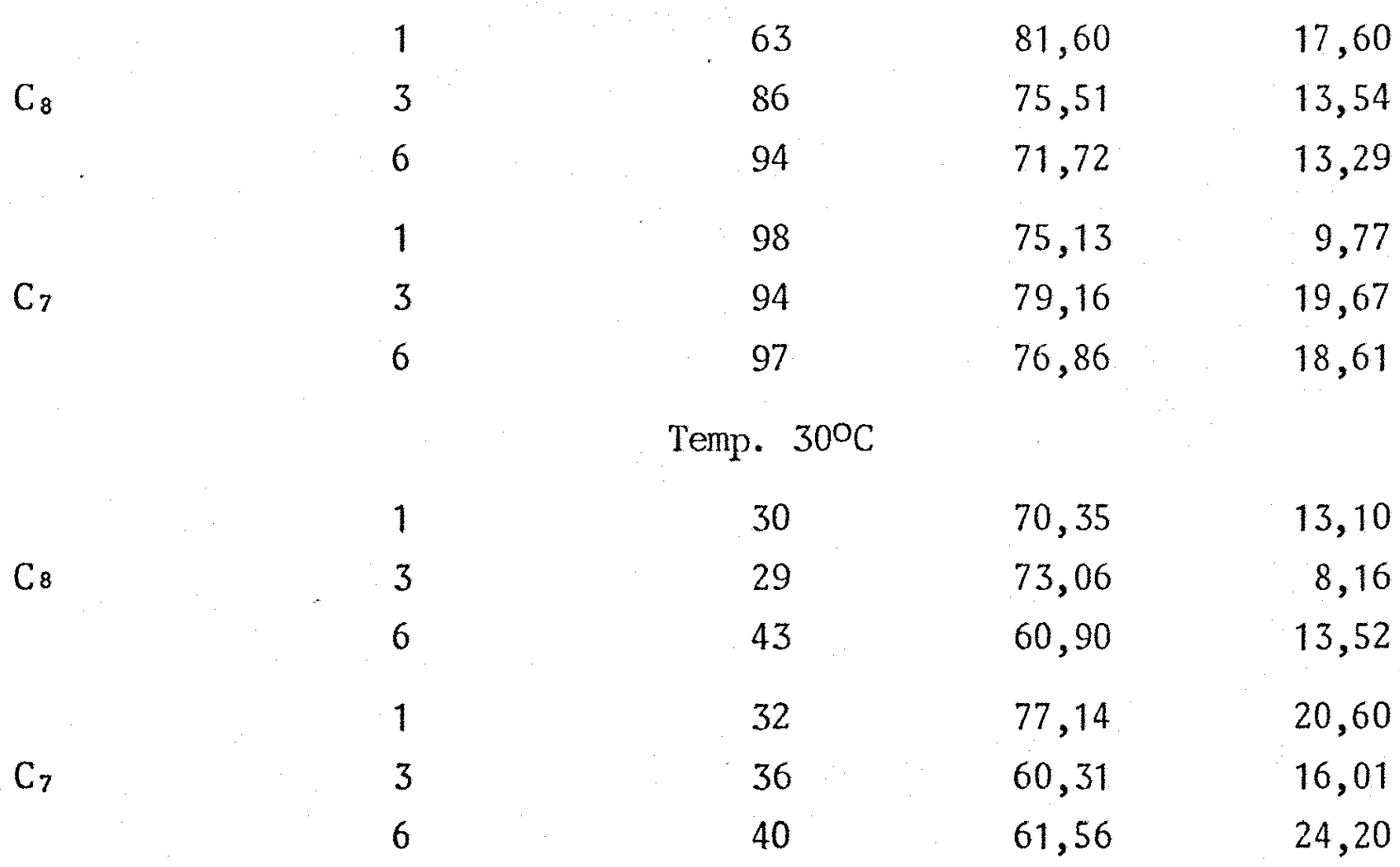


Tabela 23 - Resultados da anälise estatística para porcentagens de emergên cia de adultos de $P$. claripalpis com desenvolvimento em lagartas de $D$. saccharalis infectadas e não infectadas por $M$. aniso pliae, em diferentes temeraturas.

\begin{tabular}{lccc}
\hline & \multicolumn{3}{c}{ Temperatura $\left({ }^{\circ} \mathrm{C}\right)$} \\
\cline { 2 - 4 } & 22 & 26 & 30 \\
\hline Teste F p/condições & $3,00 \mathrm{NS}$ & $0,03 \mathrm{NS}$ & $0,02 \mathrm{NS}$ \\
Teste F p/fases & $0,47 \mathrm{NS}$ & $0,53 \mathrm{NS}$ & $1,06 \mathrm{NS}$ \\
Teste F p/interações & $1,11 \mathrm{NS}$ & $1,67 \mathrm{NS}$ & $0,73 \mathrm{NS}$ \\
C.V. & $15,317500^{\circ}$ & $17,340400^{\circ}$ & $20,995500^{\circ}$ \\
Q.M. Res. & 87,48670 & 120,34100 & 139,68100
\end{tabular}

Médias das Condições

$\begin{array}{llll}\text { Condição } 8 \text { (P.c.+M.a.) } & 57,24510 & 62,94820 & 55,90220 \\ \text { Condição } 7 \text { (P.c.) } & 64,88230 & 63,57760 & 56,68080\end{array}$

Mëdias de Fases

\begin{tabular}{llll}
\hline Fase 1 (1 dia após) & 60,09980 & 64,83130 & 61,77070 \\
Fase 2 (3 dias após) & 59,07190 & 64,35050 & 55,03770 \\
Fase 3 (6 dias após) & 64,01920 & 60,60700 & 52,06610 \\
\hline
\end{tabular}

P.c. =Paratheresia claripalpis

M.a.=Metarhizium anisopliae. 
Para os outros dois parasitos estudados, M. minense e P. claripalpis, apesar dos dados não revelar $m$ nenhuma diferença significativa nas três temperaturas, observou-se uma tendência geral de diminuição da porcentagem de emergência nos tratamentos onde os dois agentes estavam presentes, su gerindo uma interação antagônica entre o desenvolvimento do fungo e do parasito, como observado por BELL et alii (1984). Po rém, os mesmos autores concluiram que quando o efeito dos dois estressores foi combinado, uma alta mortalidade da praga foi observada, como na presente pesquisa.

4.2. EXPERIMENTO II INOCULACÄO DO Metarhizium anisopliae (METSCH.) SOROK. EM ADULTOS DE Apanteles flavipes (CAM.)

0 efeito da exposição de adultos de Apanteles Glavipes (Cam.) ao fungo Metarhizium anisopliae (Metsch.) Sorok. na concentração de $10^{7}$ conídios/ml estä representado na Tabe1a 24. Verifica-se por esta tabela que o contato direto dos adultos de A. flavipes com os conídios do M. anisopliae não foi suficiente para provocar infecção nos parasitöides, o que seria uma situação comum num campo onde ambos fossem liberados. A concentração utilizada no teste é altamente eficaz contra lagartas de $D$. saccharalis e outros insetos (ALMEIDA et alii, 1984 ; SOSA GOMEZ, 1983). 
Tabela 24 - Efeito das exposição de adultos de A. flavipes ao fungo M. ani sopliae na concentração de $10^{7}$ conídios $/ \mathrm{ml}$.

\begin{tabular}{|c|c|c|c|c|c|c|c|}
\hline \multirow[b]{2}{*}{$\begin{array}{l}\text { Temp. } \\
\left({ }^{\circ} \mathrm{C}\right)\end{array}$} & \multirow{2}{*}{ Condições } & \multirow{2}{*}{$\begin{array}{c}\text { No inse- } \\
\text { tos } \\
\text { expostos }\end{array}$} & \multicolumn{4}{|c|}{ : mortalidade ácumulada após } & \multirow{2}{*}{$\begin{array}{l}\text { No total } \\
\text { insetos } \\
\text { infecta- } \\
\text { dos }\end{array}$} \\
\hline & & & 1 dia & 2 dias & 3 dias & 4 dias & \\
\hline \multirow{2}{*}{22} & I & 99 & 12,12 & 72,72 & 77,77 & 100 & 0 \\
\hline & $\begin{array}{c}\text { IV } \\
\text { (testem.) }\end{array}$ & 123 & 8,94 & 86,18 & 100 & - & 0 \\
\hline \multirow{2}{*}{26} & II & 96 & 54,17 & 68,75 & 100 & - & 0 \\
\hline & $\begin{array}{c}\mathrm{V} \\
\text { (testem.) }\end{array}$ & 147 & 44,90 & 89,80 & 100 & - & 0 \\
\hline \multirow{2}{*}{30} & III & 134 & $47 ; 01^{\circ}$ & 74,63 & 100 & - & 0 \\
\hline & $\begin{array}{c}\text { VI } \\
\text { (testem. }\end{array}$ & 115 & 64,35 & 73,91 & 100 & - & 0 \\
\hline
\end{tabular}

4.3. EXPERIMENTO III: INOCULAÇÃO DO Metarhizium anisopliae (METSCH.) SOROK. EM ADULTOS DE Metagonistylum minense (TOWNS.) E Paratheresia claripalpis (WULP.)

0 efeito da exposição de adultos de Metagonisty lum minense (Towns.) e Paratheresia claripalpis (Wulp.) ao fun go Metarhizium anisopliae (Metsch.) Sorok. na concentração de $10^{7}$ conídios/m1 de suspensão encontra-se representado nas Tabe las 25 e 26 , respectivamente. 
Estes inimigos naturais de 0 . saccharalis, no estágio adulto, tambêm não se mostraram suscetíveis ao fungo.

Tabela 25 - Efeito da exposição de adultos de M. minense ao fungo M. aniso pliae na concentração de $10^{7}$ conídios $/ \mathrm{ml}$.

\begin{tabular}{|c|c|c|c|c|c|c|c|c|}
\hline \multirow{2}{*}{$\begin{array}{l}\text { Temp. } \\
\left({ }^{\circ} \mathrm{C}\right)\end{array}$} & \multirow{2}{*}{ Condições } & \multirow{2}{*}{$\begin{array}{l}\text { No inse- } \\
\text { tos }\end{array}$} & \multicolumn{5}{|c|}{ : mortalidade acumulada apōs } & \multirow{2}{*}{$\begin{array}{l}\text { No total } \\
\text { insetos } \\
\text { infec- } \\
\text { tados }\end{array}$} \\
\hline & & & 1 dia & 2 dias. & 3 dias & 4 dias & 5 dias & \\
\hline \multirow{2}{*}{22} & I & 52 & - & - & 1,92 & 80,77 & 100 & 0 \\
\hline & $\begin{array}{c}\text { IV } \\
\text { (testem.) }\end{array}$ & 55 & - & 1,82 & 9,09 & 78,18 & 100 & 0 \\
\hline \multirow{2}{*}{26} & II & 52 & 1,91 & 23,08 & 82,69 & 100 & - & 0 \\
\hline & $\begin{array}{c}\mathrm{V} \\
\text { (testem.) }\end{array}$ & 50 & 6,00 & 26,00 & 90,00 & 100 & - & 0 \\
\hline \multirow{2}{*}{30} & III & 51 & 11,76 & 37,25 & 96,08 & 100 & - & 0 \\
\hline & $\begin{array}{l}\text { VI } \\
\text { (testem.) }\end{array}$ & 53 & $b, 60$ & 33,96 & 86,79 & 100 & - & 0 \\
\hline
\end{tabular}


Tabela 26 - Efeito da exposição de adultos de Paratheresia claripalpis ao fungo $M$. anisopliae na concentração de $10^{7}$ conídios/ml.

\begin{tabular}{|c|c|c|c|c|c|c|c|c|}
\hline \multirow{2}{*}{$\begin{array}{l}\text { Temp. } \\
\left({ }^{\circ} \mathrm{C}\right)\end{array}$} & \multirow{2}{*}{ Condições } & \multirow{2}{*}{$\begin{array}{c}\text { No inse- } \\
\text { tos } \\
\text { expostos }\end{array}$} & \multicolumn{5}{|c|}{ : mortalidade acunulada após } & \multirow{2}{*}{$\begin{array}{c}\text { No total } \\
\text { insetos } \\
\text { infec- } \\
\text { tados }\end{array}$} \\
\hline & & & 1. dia & 2 dias & 3 dias & 4 dias & 5 dias & \\
\hline \multirow{2}{*}{22} & VII & 50 & - & - & 6,00 & 52,00 & 100 & 0 \\
\hline & $x$ & 54 & - & - & 0 & 37,04 & 100 & 0 \\
\hline \multirow{2}{*}{26} & VIII & 51 & - & 39,22 & 50,20 & 100 & - & 0 \\
\hline & $\mathrm{XI}$ & 53 & - & 52,83 & 100 & 0 & - & 0 \\
\hline \multirow{2}{*}{30} & IX & 54 & - & 7,41 & 50,60 & 96,30 & 100 & 0 \\
\hline & XII & 51 & - & - & 37,25 & 80,39 & 100 & 0 \\
\hline
\end{tabular}

4.4. EXPERIMENTO IV: INOCULACÃO DO Metarhizium anisopliae

(METSCH.) SOROK. EM MASSAS DE Apanteles flavipes

( CAM, )

o efeito da exposição de massas de Apanteles flavipes (Cam.) ao fungo Metarhizium anisopliae (Metsch.) Sorok. na concentração de $10^{7}$ conídios/ml de suspensão pode ser observado na Tabela 27 , onde se verifica que o fungo não tem nenhuma ação sobre as pupas do parasito. Apesar da inoculação ter sido 
feita por imersão, as pupas encontram-se naturalmente envolvidas por um casulo de seda que as protege do contato direto com os patógenos e dos outros inimigos naturais.

Tabela 27 - Efeito da exposição de nupas de A. flavipes ao fungo M. anisopliae na concentração de $10^{7}$ conídios/ml.

\begin{tabular}{lccccc}
\hline Temp. $\left({ }^{\circ} \mathrm{C}\right)$ & Condiçóes & No casulos \\
expostos & $\begin{array}{c}\text { Total de } \\
\text { pupas } \\
\text { viaveis }\end{array}$ & $\begin{array}{c}\text { : } \\
\text { emergência }\end{array}$ & $\begin{array}{c}\text { Total de } \\
\text { insetos } \\
\text { infectados }\end{array}$ \\
\hline 22 & A & 85 & 75 & 88,24 & 0 \\
& a & 93 & 85 & 91,40 & 0 \\
26 & B & 98 & 90 & 91,84 & 0 \\
30 & b & 101 & 90 & 89,11 & 0 \\
& C & 87 & 75 & 86,21 & 0 \\
\hline
\end{tabular}

4.5. EXPERIMERTO V: INOCULACÃO DO Metarhizium anisopliae (METSCH.) SOROK. EN PUPAS DE Metagonistylum minense (TOWNS, E Paratheresia claripalpis (WULP.)

O efeito da exposição de pupas de Metagonistylum minense (Towns.) e Paratheresia claripalpis (Wulp.) ao fun go Metarhizium anisopliae (Metsch.) Sorok. na concentração de 
$10^{7}$ conídios/ml, pode ser observado nas Tabelas 28 e 29 , respectivamente.

Tabela 28 - Efeito da exposição de pupas de Metagonistylum minense ao fungo Meiarhizium anisopliae na concentração de $10^{7}$ conídios/m1.

\begin{tabular}{|c|c|c|c|c|}
\hline Temp. $\left({ }^{\circ} \mathrm{C}\right)$ & Condições & $\begin{array}{l}\text { No pupas } \\
\text { expostas }\end{array}$ & $\begin{array}{c}\text { Total de } \\
\text { punas } \\
\text { viâaeis }\end{array}$ & $\begin{array}{c}\frac{\sigma}{0} \\
\text { emergên- } \\
\text { cia }\end{array}$ \\
\hline
\end{tabular}

\begin{tabular}{llllll}
\hline 22 & A & 50 & 45 & 90 & 0 \\
& a & 50 & 43 & 86 & 0 \\
26 & & & & 82 & 0 \\
30 & B & 50 & 41 & 82 & 0 \\
& b & 50 & 41 & & 0 \\
& C & 50 & 38 & 76 & 0 \\
\hline
\end{tabular}


Tabela 29 - Efeito da exposição de pupas de $P$. claripalpis ao fungo $M$. an $\underline{\text { }}$ sopliae na concentração de $10^{7}$ conídios/ml.

\begin{tabular}{lccccc} 
Temp. $\left({ }^{\circ} \mathrm{C}\right)$ & Condições & $\begin{array}{c}\text { No pupas } \\
\text { expostas }\end{array}$ & $\begin{array}{c}\text { Total de } \\
\text { pupas } \\
\text { viaveis }\end{array}$ & $\begin{array}{c}\% \\
\text { energencia }\end{array}$ & $\begin{array}{c}\text { Tota1 in- } \\
\text { setos } \\
\text { infectados }\end{array}$ \\
\hline 22 & D & 50 & 48 & 96 & 0 \\
& d & 50 & 45 & 90 & 0 \\
26 & E & 50 & 44 & 88 & 0 \\
& e & 50 & 45 & 90 & 0 \\
30 & F & 50 & 41 & 82 & 0 \\
& f & 50 & 43 & 86 & 0 \\
\hline
\end{tabular}

Também por essas tabelas observa-se que não hou ve ação do fungo M. anisopliae sobre esse estágio dos parasitos.

Com relação a interações de entomopatógenos com insetos parasitos existem muitos relatos contraditórios. Também, observou-se que a maioria dos trabalhos que relacionam as desvantagens das interações se referem a outros tipos de patógenos tais como bactérias, vírus e protozoários, cujo principal meio de inoculação é através da ingestão por via oral.

No tocante ao $M$. anisopliae a penetração inicia-se, freqüentemente, através do tegumento do inseto e este 
fato aliado, provavelmente, a uma maior especificidade do fungo ao inseto praga, parece ser vantajoso para os parasitos, di minuindo as possibilidades de infecção das larvas.

$$
\text { Segundo GUAGLIUMI (1974) e ALMEIDA et alii }
$$

(1984) o fungo M. anisopliae è um importante inimigo de cigarrinhas e brocas da cana, como também os parasitos estudados (ROCCIA, 1982; RISCADO, 1982 e PÁDUA, 1983). Por outro 1a do, a interação entre parasitos e fungos seria muito aconse1hāvei, já que os mesmos poderiam atuar sobre as pragas em épo cas diferentes, devido a proväveis preferências de condições climäticas.

Assim, a ocorrência natura1 ou a liberação desses agentes em um programa de manejo integrado de pragas de ca na pode ser recomendada como prática eficiente e compatível. 


\section{CONCLUSÕES}

Com base nos resultados obtidos na pesquisa podem ser tiradas as seguintes conclusões:

1. A aplicação conjunta do Metarhizium anisopliae associado aos parasitos da broca é mais eficiente que a aplicação do fungo isoladamente.

2. A inoculação do fungo Wetarhizium anisopliae não foi prejudicial aos parasitos nas diferentes fases $(1,3$ e 6 dias após a inoculação dos parasitos).

3. O fungo Metarhizium anisopliae não se mostrou patogênico aos diferentes estágios de desenvolvimento dos parasitos da broca da cana-de-açūcar. 
4. A utilização conjunta do fungo Metarhizium anisopliae e dos parasitos da broca é compatível dentro do esquema de manejo integrado de pragas da cana-de-açūcar. 


\section{LITERATURA CITADA}

AHMAD, S.; J.R. O'NEIL; D.L. MAGUE e R.K. NOWALK, 1978.

Toxicity of Bacillus thuringiensis to gypsy moth larvae parasitized by Apanteles melanoscelus. Environ. Entomo1. Maryland, $\underline{7}(1): 73-76$.

ALMEIDA, L.C.; S.B. ALVES; P.S.M. BOTEHO; N. DEGASPARI; J.R. ARAUJO, 1981a. Efeito de diferentes dosagens do Metarhizium anisopliae (Metsch.) Sorokin, isolado SPL, sobre 1arvas de Diatraea saccharalis (Fabr.). Araras, IAA/PLANALSUCAR, COSUL. 10p. 
ALMEIDA, L.C.; P.S.M. BOTELHO; S.B. ALVES; N. DEGASPARI; J.R. ARAUJO, 1981b. Efeito do Metarhizium anisopliae (Metsch.) Sorokin; sobre ovos da broca da cana, Diatraea saccharalis (Fabr.). Araras, IAA/PLANAISUCAR, COSUL. $13 \mathrm{p}$.

ALMEIDA, L.C.; S.B. ALVES; P.S.M. BOTELHO; N. DEGASPARI; J.B. PINHEIRO, 1981c. Determinação da patogenicidade do Metarhizium anisopliae (Metsch.) Sorokin, sobre ovos de Diatraea saccharalis (Fabr.), de diferentes idades. Araras, IAA/PLANALSUCAR, COSUL. 12p.

ALMEIDA, L.C. e S.B. ALVES, 1982. Testes preliminares de dosagens de Metarhizium anisopliae (Metsch.) Sorok., para o controle da broca da cana-de-açúcar, Diatraea saccharalis (Fabr.). Brasil Acucareiro. Rio de Janeiro, 99(2): 35-38.

ALMEIDA, L.C., 1983. Efeito das radiacões gama e ultravioleta em isolados de Metarhizium anisopliae (Metsch.) Sorokin, 1883 e sua utilização visando o controle da Diatraea saccharalis (Fabricius, 1794). Piracicaba, ESALQ/USP, 109p. [Dissertação de Mestrado]. 
ALMEIDA, L.C.; S.B. ALVES; N. DEGASPARI; J.R. de ARAUJO, 1984. Efeito "in vitro" de diferentes dosagens do Metarhizium anisopliae (Metsch.) Sorok, isolado SPL, sobre larvas de Diatraea saccharalis (Fabr,). STAB. Rio de Janeiro, 2(3): $49-53$.

ALVES, S.B., 1982. Caracterização, padronização e produção do Metarhizium anisopliae (Metsch.) Sorok. Piracicaba, ESALQ/ USP, 95p. [Tese de Livre Docência].

ALVES, S.B. e J.W.N. CHAVES, 1984a. Efeito de diferentes temperaturas no desenvolvimento e esporulação do Aspergillus sp. Ecossistema. Espírito Santo do Pinha1, 9: 84-86.

ALVES, S.B.; S.H. RISCO e L.C. ALMEIDA, 1984b. Inf1uence of photoperiod and temperature on the development and sporulation of Metarhizium anisopliae (Metsch.) Sorok. Zeitschriff für angewandte Entomologie. Hamburgo, 2: $127-$ -129 .

ANDREASIS, T.G., 1980. Nosema pyrausta infection in Macrocentrus grandie, a braconid parasite of the European corn borer, Ostrinia nubilalis. J. Invertebr. Patho1. New York, 33: 229-233. 
AQUINO, M.L.N., 1974. O fungo entomógeno Metarhizium anisopliae (Metsch.) Sorokin no Estado de Pernambuco. Boletim Técnico do Instituto de Pesquisas Agronômicas. Recife, 72: $1-26$.

BEEGLE, C.C. e E.R. OATMAN, 1975. Effect of a nuclear polyhedrosis virus on the relationsthip between Trichoplusia $n i$ (Lepidoptera:Noctuidae) and the parasite, Hyposoter exiguae (Hymenoptera:Ichneumonidae). J. Invertebr. Pathol. New York, 25: 59-71.

BELL, J.V. e R.J. HAMALLE, 1971. A bacterium and dipterous parasite in wild populations of cowpea Curculio larvae: effects of treatment with spores of Metarhizium anisopliae. J. Invertebr. Patho1. New York, 17: 256-259.

BELL, J.V.; E.G. KING e R.J. HAMALLE, 1974. Interactions between bollworms, a braconid parasite and the bacterium Serratia marcescens. Ann. Entomol: Soc. Am. Columbus,

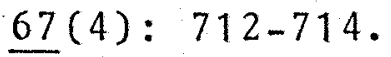

BELL, M.R. e W.L. McGOVEkN, 1975. Susceptibility of the ectoparasite, Bracon mellitor, to infection by microsporidan pathogens in its host, Anthonomus grandis. J. Invertebr. Patho1. New York, 25: 133-134. 
BERISFORD, Y.C. e TSAO, C.H., 1975. Parasitism, predation, and disease in the bagworm, Thyridopteryx ephemeraeformis (Haworth) (Lepidoptera:Psychidae). Environ. Entomol. Maryland, 4(4): 549-554.

BRACKEN, G.K. e G.E. BUCHER, 1967. Mortality of Hymenopterous parasite caused by Serratia marcescens. J. Invertebr. Patho1. New York, 9: 130-132.

BROOKS, W.M. e J.D. CRANFORD, 1972. Microsporidoses of the hymenopterous parasites, Campoletis sonorensis and cardiochiles nigriceps, larval parasites of Heliothis species. J. Invertebr. Patho1. New York, 20: 77-94.

BROOKS, W.M., 1973. Protozoa: Host-parasite-pathogen interre1ationships. Misc. Pub1. Entomo1. Soc. Am., 9: 105-111 .

BURLEIGH, J.G., 1975. Comparison of Heliothis spp. 1arval parasitism and spicaria infection in closed and open canopy cotton. Environ. Entomol. Maryland, 4: 574-576.

COSENZA, G.W.; R.P. ANDRADE; D.T. GOMES; C.M. CAMPOS da ROCHA, 1981. O controle biológico das cigarrinhas das pastagens. Comunicado Técnico, EMBRAPA - Planaltina, (17): 1-6. 
DILAWARI, J.K.; M.S. MAHAL e S.S. BAINS, 1981. Role of a braconid parasite and a viral disease in the population decline of armyworm, Mythimna separata during and outbreak. Indian J. Eco1. Ludhiana, 8(1): 65-73. Apud: Abstr. Entomol., 13(7): 8 .

DUNBAR, J.P. e A.W. JOHNSON, 1975. Bacillus thuringiensis: Effects on the survival of a tobacco budworm parasitoid and predator in the laboratory. Environ. Entomol. Maryland, $4(2): 352-354$.

EL-SUFTY, R.; E. FÜHRER, 1981. Interrelationships between Pieris brassicae L. (Lep., Pieridae), Apanteles glomeratus L. (Hym., Braconidae) and the fungus Beauveria bassiana [Bals.) Vuil1]. Zeitschrift für Angcwandte Entomologie, 92(4), 321-329, Kafr E1-Sheikh, Egypt. Apud: R. App1. Entomol. London, 1982, $\underline{70}(3): 219$.

FERRAZ, M.C.V.D.; J.S. CORREIA; E.A.F. DA MATA; J.A. COSTA, 1980. Estudo da eficiência do fungo Metarhizium anisopliae (Metsch.) Sorokin, no controle das cigarrinhas das pastagens. In: Congresso Brasileiro de Entomologia, 6, Campinas p.354. [Resumo, R-252]. 
GUAGLIUMI, P., 1970. A cigarrinha das pastagens ataca a cana-de-açūcar no Nordeste do Brasil. Brasil Açucareiro. Rio de Janeiro, 76(4): 89-91.

GUAGLIUMI, P., 1971. Lucha integrada contra las cigarrinhas (Hom.: Cercopidae) en el noroeste del Brasil. Revista Peruana de Entomología. Lima, 14: 361-368.

GUAGLIUMI, P., 1972. Resultados preliminares da luta biológica contra a cigarrinha da folha e da cana-de-açúcar no Estado de Pernambuco. Brasil Acucareiro. Rio de Janeiro, 80 (3): $49-51$.

GUAGLIUMI, P.; E.J. MARCUES; A.M. VILAS BOAS, 1974. Contribuição ao estudo da cultura e aplicação de Metarhizium anisopliae (Metsch.) Sorok., no controle da cigarrinha da folha (Mahanarva posticata, Sta1) no Nordeste do Brasil. Boletim Técnico da CODECAP. Recife, PE, 3: 54 .

HAMM, J.J.; D.A. NORDLUND; B.G. MULLINIX Jr., 1983. Interaction of the microsporidium Vairimorpha sp. With Microplits croceips (Cresson) and Cotesia marginiventris (Creson) (Hymenoptera:Braconidae), two parasitoids of Heliothis zea (Boddie) (Lepidoptera:Noctuidae). Environ. Entomol. Maryland, $12(5): 1547-1550$. 
HOSTOUNSKY, Z., 1970. NOsema mesnili (Pai11.), a microsporidian of the cabbageworm, Pieris brassicae (L.), in the parasites Apanteles glomeratus (L.), Hyposoter ebenimus (Grav.) and Pimpla instigator (F.). Acta ent. bohemoslov. 67pt. 1pp. 1-5. Apud: R. App1. Entomo1. London, 1971, 59: 928-929.

IGNOFFO, C.M.; N.L. MARSTON; D.L. HOSTETTER e B. PUTTLER, 1976. Natural and inauced epizootics of Nomuraea rileyi in soybean caterpillars. J. Invertebr. Pathol. New York, 27: $191-198$.

IBARAGON, T.A. e W.M. BROOKS, 1974. Interaction of Campoletis sonorensis and a nuclear polyhedrosis virus in larvae of Heliothis virescens. J.Econ. Entomol. Menasha, 67(2): $229-231$.

JAQUES, R.P., 1965. The effect of Bacillus thuringiensis Berliner on the fauna of an apple orchard. Canad. Entomo1. Ottawa, 97: 795-802.

JAQUES, R.P. e O.N. MORRIS, 1981. Compatibility of pathogens with other methods of pest control and with different crops. In: BURGES, H.D. Microbial Control of pests and plant diseases 1970-1980. Academic Press Inc. (London), p. 695-715. 
KAYA, H.K., 1970. Toxic factor produced by a granulosis virus in armyworm larva: effect on Apanteles militaris. Science. Washington, 168: 251-253.

KAYA, H.K. e Y. TANADA, 1973. Hemolymph factor in armyworm larvae infected with a nuclear-polyhedrosis virus toxic to Apanteles militaris. J. Invertebr. Patho1. New York, 21: $211-214$.

KAYA, H.K., 1978. Interaction between Neoaplectana carpocapsae (Nematoda:Steinernematidae) and Apanteles militaris (Hymenoptera: Braconidae), a parasitoid of the armyworn, Pseudaletia unipuncta. J. Invertebr. Patho1. New York, 31: 358-364 .

KENDRIK, W.B., 1971. Taxonomy of fungi imperfecti. University of Toronto Press. $390 \mathrm{p}$.

KING, E.G. e J.V. BELL, 1978. Interaction between a Braconid, Microplitis croceipes, and a fungus, Nomuraea rileyi, in laboratory - reared bollworm larvae. J. Invertebr. Pathol. New York, 31: 337-340. 
LAIGO, F.M. e J.D. PASCHKE, 1968. Pteromalus puparum L. parasites reared from granulosis and microsporidiosis infected Pieris rapae L. chrysalids. Phillipp. Agric. College, 52: $430-439$.

MACEDO, N.; A.C.M. MENDES; P.S.M. BOTELHO e J.A. MAGRO, 1977. Metarhizium anisopliae (Metsch.) Sorokin, no controle da cigarrinha da raiz (Mahanarva fimbriolata Stal) na cultura da cana-de-açúcar. Brasil Açucareiro. Rio de Janeiro, 90(2): $16-19$.

MARCHAL-SEGAULT, D., 1974. Sensibilité des Hyménoptères Braconides Apanteles glomeratus et Phanerotoma flavitestacea au complexe spores-cristaux de Bacillus thuringiensis Berliner. Ann. Zool. Ecol. anim. Paris, 6(4): 521-528.

McCOY, C.W., 1981. Pest control by the fungus Hirsutella thompsonii. In: BURGES, H.D. Microbial control of pests and plant diseases 1970-1980. Academic Press Inc. (London). p.499-512.

MENDONCA, A.F. e J.M. COSTA, 1980. O problema de controle integrado a cigarrinha da folha, Mahanarva posticata(Stal) (Homoptera:Cercopidae) no Estado de Alagoas durante a campanha de 1979. Resultados e perspectivas futuras. V Encontro Nacional de Entomologistas do IAA/PLANALSUCAR, Itajaí, SC, 14-19 de abri1. 
MENDES, A.C.; P.S.M. BOTELHO; N. DEGASPARI E S.M.S.S. ARAUJO, 1980. Desenvolvimento do combate biológico da Diatraea saccharalis (Fabr., 1794) (Lep.: Pyralidae), na Coordenadoria Regional Sul, importância, resultados e perspectivas futuras. In: V Encontro Nacional dos Entomologistas do IAA/PLANALSUCAR, Itajaí, SC, 14-19 de abril.

NAVES, M.A., 1981. Bioassay para testes de virulência de cepas de Metarhizium anisopliae (Metsch.) Sorokin nas cigarrinhas das pastagens Deois flavopicta (Stal) e Zulia entreriana (Berg.) (Homoptera:Cercopidae). In: Congresso Brasileiro de Entomologia, 7, Fortaleza, p.278. [Resumo, T-252].

NAVES, M.A. e R.T. AlveS, 1983. Comparação de cepas e dosagens de Metarhizium anisopliae em campo. Boletim do Grupo de Pesquisadores de Controle Biológico. Brasilia, (4): $8-10$.

PACHECO, J.M. e M.G. BERNARDES, 1976. Ensaio de campo com o fungo entomógeno Metarhizium anisopliae (Metsch.) Sorok. em três concentrações de esporos, visando o controle microbiológico da "cigarrinha das pastagens" Zulia entreriana Berg., no Norte do Estado do Espírito Santo, Brasil. In: Congresso Brasileiro de Entomologia, 3, Maceiö, 1976. p.51-2. [Resumo, 20]. 
PĀDUA, L.E.M., 1983. Biologia comparada de Apanteles flavipes (Cameron, 1891) (Hymenoptera, Braconidae) para determinação das suas exigências térmicas. Piracicaba, ESALQ/USP, 53p. [Dissertação de Mestrado].

PETCH, T., 1931. Notes on entomogenous fungi. Trans. Brit. Myc. Soc. Cambridge, 16: 55-75.

PHADKE, C.H. e V.G. RAO, 1978. Studies on the entomogenous fungus Nomuraea rileyi (Farlow) Samson. Current Science, 47(14): $511-512$.

REARDON, R.C. e J.D. PODGWAITE, 1976; Disease-parasitoid relationships in natural populations of Lymantria dispar (Lep., Lymantriidae) in the Northeastern United States. Entomophaga. Paris, 21(4):333-341.

RISCO, B.S.H., 1978. National program of sugarcane improvement, develops a multiplication program of the fungus Metarhizium anisopliae for biological control of Mahanarva posticata in the States of Northeast of Brazil. International Society of Sugarcane Technologists. Entomology Newsletter. Araras, 5: 17-18. 
RISCADO, G.M., 1982. Eficiência comparada de Apanteles flavipes (Cameron, 1891), no controle de Diatraea spp. no Rio de Janeiro. Piracicaba, ESALQ/USP, 77p. [Dissertação de Mestrado].

RoCCIA, A.0., 1982. Efeito da liberação dos parasitos Metagonistylum minense Wulp., 1896 e Lixophaga diatraeae Townsend, 1916 (Diptera:Tachinidae) no controle da broca da cana-de-açücar, Diatraca saccharalis (Fabricius, 1794) (Lep., Pyra1idae]. Piracicaba, ESALQ/USP, 45p. [Dissertação de Mestrado].

ROCKWOOD, L.P., 1950. Entomogenous fungi of the genus Metarhizium on wireworms in the Pacific Northwest. Ann. Entomol. Soc. Am. Columbus, 43 4 (4): 495-498.

RORER, J.B., 1910. The froghonner fungus, Bul1. Dept. Agric. Trinidad Tobago, 9 : 182-184.

RORER, J.B., 1913. The use of the green muscardine fungus in the control of some sugar cane pests. Phytopathology. St. Paul, 3: $88-94$. 
SHOREY, H.H. e I.M. HALL, 1963. Toxicity of chemical and microbial insecticides to pest and beneficial insects on poled tomatoes. J. Econ. Entomol. Menasha, 56 (6): $813-817$.

SMITH, J.W.; E.G. KING e J.B. BELL, 1976. Parasites and pathogens among Heliothis species in the control Mississipi Delta. Environ. Entomol. Maryland, $\underline{5}(2): 224-226$.

SOSA GŌMEZ, D.R., 1983. Caracterização e padronização de isolados de Metarhizium anisopliae (Metsch.) Sorokin, 1883 provenientes de diferentes regiões do Brasil. Piracicaba, ESALQ/USP, 117p. [Dissertação de Mestrado].

STEINHAUS, E.A., 1949. Principles of insect pathology. McGrawHil1 Publications in the Agricultural Sciences. R.A. Brink, Consulting Editor. $757 \mathrm{p}$.

TANADA, Y., 1955. Field observation on a microsporidian parasite of Pieris rapae (L.) and Apanteles glomeratus (L.). Proc. Hawaii Entomo 1. Soc., 15:609-616. Apud: R. App1. Entomo1., London, 1956, 44: 432 . 
THOMSON, H.M., 1958. The effect of a microsporidian parasite of the spruce budworm, Choristoneura fumiferana (C1em.) on two internal hymenopterous parasites. Can. Entomol. Ottawa, XC (12): 694-696.

TULLOCH, N., 1976. The genus Metarhizium. Transaction of the Brit. Mycol. Soc. Cambridge, 66: 407-411.

VAIL, P.V.; C.F. SOO HOO; R.S. SEAY; R.G. KILLINEN E W.W. WOLF, 1972. Microbial control of lepidopterous pests of fall lettuce in Arizona and effects of chemical and microbial pesticides on parasitoids. Environ. Entomo1. Maryland, $1(6): 780-785$.

VEIGA, A.F.S.L., 1979. O fungo entomógeno Metarhizium anisopliae (Metsch.) Sorok., como opção para o controle biológico das cigarrinhas das pastagens (Homoptera:Cercopidae) no Estado de Pernambuco. Boletim do Grupo de Pesquisadores de Controle Biológico. Brasilia, (1): 3-4.

VILLACORTA, A., 1980. Suscetibilidade de ninfas de Deois blavopicta (Sta1, 1854) (Homoptera, Cercopidae) a diferentes isolamentos de Metarhizium anisopliae (Metsch.) Sorokin. Anais da S.E.B. Jaboticaba1, $\underline{9}(1): 33-38$. 
WOLLAM, J.D. e W.G. YENDOL, 1976. Evaluation of Bacillus thuringiensis and a parasitoid for supression of the gypsy moth. J.Econ. Entomol. Menasha, 69(1): 113-118. 